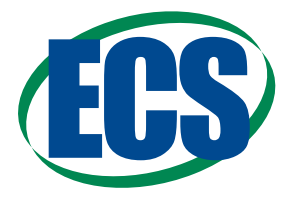

\title{
Electrolyte and SEI Decomposition Reactions of Transition Metal Ions Investigated by On-Line Electrochemical Mass Spectrometry
}

\author{
Sophie Solchenbach, $\odot^{*, z}$ Gloria Hong, Anna Teresa Sophie Freiberg, Roland Jung, [ \\ and Hubert A. Gasteiger**
}

Chair of Technical Electrochemistry, Department of Chemistry and Catalysis Research Center, Technical University of Munich, Garching, Germany

\begin{abstract}
We use on-line electrochemical mass spectrometry (OEMS) to elucidate and quantify the electrolyte reduction on graphite caused by transition metal ions. To have a controlled system, we use ethylene carbonate (EC) with $1.5 \mathrm{M} \mathrm{LiPF}_{6}$ and representative amounts of $\mathrm{Ni}(\mathrm{TFSI})_{2}$ or Mn(TFSI $)_{2}$ as model electrolytes, combined with a 2-compartment cell in which anolyte and catholyte are separated by an impermeable solid lithium ion conductor. Focusing on $\mathrm{C}_{2} \mathrm{H}_{4}$ evolution as a marker for $\mathrm{EC}$ reduction, we find that both $\mathrm{Ni}^{2+}$ and $\mathrm{Mn}^{2+}$ lead to enhanced gas evolution on pristine graphite electrodes once the potential is decreased to below the $\mathrm{TM}^{2+} / \mathrm{TM}^{0}$ redox potential, demonstrating that the reduced transition metals are active toward electrolyte reduction. If the electrodes are preformed in a TM-free electrolyte and subsequently cycled in an electrolyte containing either $\mathrm{Mn}^{2+}$ or Ni ${ }^{2+}$, the activity of nickel toward electrolyte decomposition is greatly reduced, whereas the electrolyte with manganese still shows a strong ongoing $\mathrm{C}_{2} \mathrm{H}_{4}$ generation. The use of vinylene carbonate during formation partially suppresses the gas evolution from manganese. Using OEMS and post-mortem ATR-FTIR, we finally show that reduced manganese can decompose organic SEI components into $\mathrm{Li}_{2} \mathrm{CO}_{3}$, thereby compromising the integrity of the SEI and enabling the additional reduction of electrolyte.

(C) The Author(s) 2018. Published by ECS. This is an open access article distributed under the terms of the Creative Commons Attribution 4.0 License (CC BY, http://creativecommons.org/licenses/by/4.0/), which permits unrestricted reuse of the work in any medium, provided the original work is properly cited. [DOI: 10.1149/2.0511814jes]

(cc) BY
\end{abstract}

Manuscript submitted August 30, 2018; revised manuscript received October 11, 2018. Published October 23, 2018.

Transition metal (TM) dissolution is a long-known degradation phenomenon of lithium manganese spinel-type cathode active materials for Li-ion batteries. It is amplified by temperature, ${ }^{1,2}$ high cathode potentials, ${ }^{3}$ and large BET surface area of the particles. ${ }^{3}$ As layered lithium nickel cobalt manganese oxide (NCM) cathode materials are cycled to higher cutoff potentials to maximize the energy density of Li-ion cells, transition metal dissolution also becomes significant for NCMs. ${ }^{4-11}$ Experimental and ab initio modeling studies suggest that the electrochemical oxidation of $\mathrm{LiPF}_{6}$-based electrolytes at high voltages $^{8,12-17}$ and/or follow-up reactions of the electrolyte with oxygen released from the NCM host lattice ${ }^{18-22}$ can generate HF, which then corrodes the layered transition metal oxide cathode materials. Upon lattice oxygen release (occurring upon delithiation to $\sim 80 \%$ in NCMs), ${ }^{18,19}$ not only manganese, but also nickel and cobalt are dissolved as $\mathrm{TM}^{2+}$ ions into the electrolyte ${ }^{4}$ at concentration ratios that reflect the stoichiometry of the bulk material..$^{5,7,23}$

The most apparent consequences of transition metal dissolution are capacity and power fade..$^{3,6-9,24-28}$ However, the amount of dissolved cathode active material is typically less than $1 \%,^{7,9,26,28-30}$ which is too low to explain the observed capacity losses. Instead, the transition metal ions deposit on the graphite anode, where they lead to a significant decrease of the coulombic efficiency and to a large increase in anode impedance..$^{5-7,9,24,25,31-34}$ It is not fully understood how transition metal ions can cause these detrimental effects, yet the negative impact of manganese on graphite anode capacity retention is considerably worse compared to nickel and cobalt. ${ }^{5,7,31}$

Recent studies have shown that $\mathrm{Mn}^{2+}$ ions exchange rapidly with $\mathrm{Li}^{+}$ions contained in the solid electrolyte interphase (SEI), as evidenced by soaking either preformed graphite electrodes ${ }^{24,35,36}$ or single SEI compounds such as $\mathrm{LiF}$ or $\mathrm{Li}_{2} \mathrm{CO}_{3}{ }^{25,37}$ in $\mathrm{Mn}^{2+}$-containing electrolytes. Furthermore, $\mathrm{Mn}^{2+}$ ions were found to accumulate at the interface between organic (outer) and inorganic (inner) SEI in EC-based electrolytes without additives. ${ }^{25,32,37,38}$ While some groups identified exclusively $\mathrm{Mn}(+\mathrm{II})$ species like $\mathrm{MnCO}_{3}$ and $\mathrm{MnF}_{2},{ }^{24,35,39-41}$ others found also reduced manganese in its 0 or +1 oxidation state on lithiated graphite. ${ }^{33,38,42,43}$ Considering that nano-sized transition metal carbonates and -fluorides have been tested as conversion-type anode materials, ${ }^{44-48}$ a reduction of these species in the SEI to metallic manganese seems likely. However, since the irreversible capacity on

\footnotetext{
*Electrochemical Society Student Member.

**Electrochemical Society Fellow.

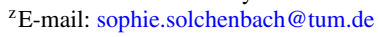

graphite anodes is typically 30-50 times higher than the capacity required for a 2-electron reduction of the accumulated manganese, ${ }^{2,7,28}$ additional side reactions must be taking place, consuming active lithium. One proposed hypothesis is that reduced manganese in contact with electrolyte re-oxidizes to $\mathrm{Mn}^{2+}$ by simultaneously reducing solvent molecules, ${ }^{4,33,39}$ as supported by DFT calculations from Han et al. $^{49}$ If then the $\mathrm{Mn}^{2+}$ ions can be reduced again, a catalytic cycle would be established by which active lithium would be lost continuously into the SEI. While this appears plausible, the question remains why manganese would not eventually be covered by SEI species that would prevent new solvent molecules from reaching the active TM center, and thus would stop the electrolyte reaction with the TM center. To resolve this question, Leung ${ }^{50}$ and Joshi et al. ${ }^{32}$ suggested that transition metals also decompose organic SEI species, thus compromising the passivating properties of the SEI.

Despite the many mechanistic insights gained by the above described studies, the nature of the electrolyte or SEI decomposition reactions associated with manganese deposited on graphite anodes remains unclear. Moreover, the number of analogous studies on the effect of nickel ions is limited, ${ }^{31}$ although nickel is the most commonly dissolved transition metal from Ni-rich NCMs and NCA.,7 The scientific debate is further complicated, as the typical sample washing and/or drying steps required for conducting detailed ex-situ diagnostics like X-ray photoelectron spectroscopy (XPS), X-ray absorption spectroscopy (XAS) or scanning electron microscopy (SEM) can easily affect the transition metal oxidation state., ${ }^{4,43}$ Therefore, the use of operando techniques for investigating the transition metal redox mechanism in the SEI has become imperative.

In this work, we use on-line electrochemical mass spectrometry (OEMS) to investigate the fundamental reactions of carbonate based electrolytes with nickel and manganese ions on a graphite anode. In order to mimic the effect of a typical dissolution of $\sim 0.3 \mathrm{wt} \%$ of the cathode active material observed in the above discussed studies, we use an ethylene carbonate $(\mathrm{EC}) / \mathrm{LiPF}_{6}$ model electrolyte containing $\mathrm{Mn}^{2+}$ or $\mathrm{Ni}^{2+}$ ions at the corresponding amounts. To avoid deposition of the transition metal ions on the lithium counter electrode, we use a sealed 2-compartment cell setup, separating the working and counter electrode compartments by a lithium ion conducting solid electrolyte. ${ }^{12}$ As ethylene is the major gaseous product of the reductive decomposition of EC, ${ }^{51,52}$ we will especially focus on its evolution during formation and cycling of graphite electrodes in $\mathrm{Mn}$ - or $\mathrm{Ni}$-containing electrolytes. Considering that in real lithium-ion cells, transition metal dissolution occurs predominantly after the battery formation process 
is completed, we also investigate the effect of manganese and nickel ions on graphite electrodes that were preformed in a TM-free electrolyte. Finally, we use attenuated total reflection Fourier-transformed infrared (ATR-FTIR) spectroscopy and OEMS to elucidate the reactions of transition metal ions with SEI species.

\section{Experimental}

Preparation of electrodes and electrolytes.-Graphite electrodes were prepared by mixing graphite (SLP30, $7 \mathrm{~m}^{2}{ }_{\text {BET }} / \mathrm{g}$, Timcal, Switzerland) and polyvinyl difluoride (PVDF, Kynar HSV 900, Arkema, France) in a ratio of 95:5 with N-methyl-pyrrolidone (NMP, anhydrous, Sigma-Aldrich, Germany; ink solid content $40 \%$ ) in a planetary mixer (Thinky Corp., USA) at $2000 \mathrm{rpm}$ for $15 \mathrm{~min}$. The ink was then coated onto a polyester separator (FS 24316, Freudenberg, Germany) and dried at $50^{\circ} \mathrm{C}$ for $10 \mathrm{~h}$. Electrodes with $15 \mathrm{~mm}$ diameter were punched out, dried in a glass oven (Büchi, Switzerland) under dynamic vacuum at $120^{\circ} \mathrm{C}$ for $12 \mathrm{~h}$ and transferred into the glove box without exposure to air. The final electrodes had a loading of $6.1 \pm 0.2 \mathrm{mg}_{\mathrm{SLP} 30} / \mathrm{cm}^{2}\left(\equiv 2.3 \mathrm{mAh} / \mathrm{cm}^{2}\right)$. Glassfiber and polyester separators were also dried at $120^{\circ} \mathrm{C}$ under dynamic vacuum prior to use.

Electrolytes were prepared by mixing $\mathrm{LiPF}_{6}$ (BASF SE, Germany) with ethylene carbonate (EC, BASF SE, Germany) or dimethyl carbonate (DMC, BASF SE, Germany) to yield a $1.5 \mathrm{M} \mathrm{LiPF}_{6}$ concentration. For preformation of graphite anodes with an SEI-forming additive, vinylene carbonate (VC, BASF SE, Germany) was added at a concentration of $2 \mathrm{wt} \%$ to the as-prepared $\mathrm{DMC}^{\mathrm{L}} \mathrm{LiPF}_{6}$ electrolyte. Manganese bis-(trifluorosulfonyl)imide (Mn(TFSI) $2,99.5 \%$, Solvionic, France) and nickel bis-(trifluorosulfonyl)imide (Ni(TFSI), 97\%, Alfa Aesar, United States) were dried under dynamic vacuum at $120^{\circ} \mathrm{C}$ for 3 days and added to the electrolytes to yield a metal concentration of $10 \mathrm{mM}$, corresponding to a total amount of $1.5 \mu \mathrm{mol}$ in the cell or $0.85 \mu \mathrm{mol} / \mathrm{cm}^{2}$ per geometric graphite electrode area (based on $150 \mu \mathrm{L}$ electrolyte and $\varnothing 15 \mathrm{~mm}$ electrodes). For a full-cell with our graphite anodes and a balanced cathode with a loading of $13.5 \mathrm{mg} \mathrm{CAM}_{\mathrm{CAM}} / \mathrm{cm}^{2}$ ( $\equiv 2.2 \mathrm{mAh} / \mathrm{g}$ for a specific capacity of $165 \mathrm{mAh} / \mathrm{g}$ ), the total amount of dissolved transition metal would translate to $\sim 3.4 \mathrm{mg}_{\mathrm{TM}} / \mathrm{g}_{\mathrm{CAM}}$ or $\sim 0.3 \mathrm{wt} \%$.

On-line electrochemical mass spectrometry.-The online electrochemical mass spectrometry (OEMS) system and a standard one-compartment electrochemical cell have been described in our previous publication. ${ }^{53}$ To avoid the deposition of TM ions on the Li metal counter electrode, a sealed 2-compartment cell was used, where working and counter electrode compartments are separated by an impermeable lithium-ion conductive glass ceramic (LICGC, Ohara Corp., Japan) with an aluminum foil edge-seal. ${ }^{12,54}$ The counter electrode compartment, which is shielded from the OEMS inlet, contained the Li counter electrode ( $\varnothing 17 \mathrm{~mm}, 450 \mu \mathrm{m}$ thickness, Rockwood Lithium, United States) and a $22 \mathrm{~mm}$ diameter glass fiber separator soaked with $250 \mu \mathrm{L} \mathrm{EC}+1.5 \mathrm{M} \mathrm{LiPF}_{6}$ or $\mathrm{DMC}+1.5 \mathrm{M} \mathrm{LiPF}_{6}$ without any transition metal ions added. The working electrode compartment that is connected to the OEMS inlet contained the graphite working electrode $(\varnothing 15 \mathrm{~mm})$ and a polyester separator $(\varnothing 17 \mathrm{~mm})$, both soaked with $150 \mu \mathrm{L}$ of the test electrolyte, i.e., with or without TM salts added. After connection to the OEMS inlet and a rest period at open circuit voltage $(\mathrm{OCV})$ for $4 \mathrm{~h}$, we performed cyclic voltammetry at a rate of $0.2 \mathrm{mV} / \mathrm{s}$, starting from $\mathrm{OCV}\left(\sim 3 \mathrm{~V} \mathrm{vs} . \mathrm{Li}^{+} / \mathrm{Li}\right)$ and then scanning between $0.1 \mathrm{~V}$ and $2 \mathrm{~V}$ or $3 \mathrm{~V}$ vs. $\mathrm{Li}^{+} / \mathrm{Li}$. For quantification of the mass spectrometer currents, a calibration gas containing $\mathrm{H}_{2}$, $\mathrm{O}_{2}, \mathrm{CO}_{2}$, and $\mathrm{C}_{2} \mathrm{H}_{4}$ (each 2000 ppm) or $\mathrm{H}_{2}, \mathrm{O}_{2}, \mathrm{CO}_{2}$, and $\mathrm{CO}$ (each $2000 \mathrm{ppm}$ ) in Argon (Linde AG, Germany) was used. All currents were normalized to the current at $\mathrm{m} / \mathrm{z}=36$ (Ar isotope) in order to correct for effects of minor pressure and temperature deviations, and afterwards the currents $\mathrm{m} / \mathrm{z}=2\left(\mathrm{H}_{2}\right), \mathrm{m} / \mathrm{z}=26\left(\mathrm{C}_{2} \mathrm{H}_{4}\right), \mathrm{m} / \mathrm{z}=$ $28\left(\mathrm{CO}\right.$, corrected for contributions from $\mathrm{C}_{2} \mathrm{H}_{4}$ and $\mathrm{CO}_{2}$ as described by Strehle et al.), ${ }^{55}$ and $\mathrm{m} / \mathrm{z}=44\left(\mathrm{CO}_{2}\right)$ were converted into gas concentrations.
For experiments with preformed electrodes, graphite electrodes coated on polyester separator were cycled 2 times with a rate of $\mathrm{C} / 8$ (based on graphite capacity) vs. a LFP electrode $\left(3.5 \mathrm{mAh} / \mathrm{cm}^{2}\right.$, Custom Cells, Germany) in EC/1.5 $\mathrm{M} \mathrm{LiPF}_{6}$ electrolyte between 3.45 and $2 \mathrm{~V}$ cell voltage. The preformed cells were then discharged to $0.3 \mathrm{~V}$ cell voltage (corresponding to a graphite potential $\sim 2.9 \mathrm{~V}$ vs. $\mathrm{Li}^{+} / \mathrm{Li}$ ) and held at this potential for $10 \mathrm{~h}$. Subsequently, the cells were disassembled inside a glove box, and the graphite electrodes were transferred without further washing into another OEMS cell with freshly prepared electrolyte and separators. For the experiments with graphite electrodes stored/preformed in EC and cycled in DMC as well as for graphite electrodes preformed in DMC/1.5 $\mathrm{M} \mathrm{LiPF}_{6}+$ $2 \mathrm{wt} \% \mathrm{VC}$, the graphite electrodes were washed with $5 \mathrm{~mL}$ DMC prior to the assembly of the OEMS cell in order to remove any remaining electrolyte contained in the pores of the harvested graphite electrodes.

Attenuated total reflection fourier-transform infrared spectroscopy (ATR-FTIR).--For ATR-FTIR analysis, both LFP cathode and graphite anode from the preformed cells (cycled at $\mathrm{C} / 8$ in $\mathrm{EC}+$ 1.5 $\mathrm{M} \mathrm{LiPF}_{6}$ between 2.0-3.45 $\mathrm{V}_{\text {cell }}$ ) were transferred into a new cell with fresh separators and electrolyte with/without transition metals, and cycled again for 2 cycles at $\mathrm{C} / 8$ between the same cell voltages. The cells were then disassembled inside an Ar-filled glove box. The graphite electrodes were washed with $1.5 \mathrm{~mL}$ DMC and dried for 20 min under dynamic vacuum in the glove box antechamber at room temperature. ATR-FTIR spectra of the electrodes were then measured inside the glove box using a Spectrum Two spectrometer (Perkin Elmer) with a resolution of $4 \mathrm{~cm}^{-1}$ with 128 scans on a MIRacle germanium ATR (Pike Technologies). The spectra were normalized to the intensity of the PVDF peak at $1190 \mathrm{~cm}^{-1}\left(-\mathrm{CF}_{2}-\right.$ stretching vibrations). ${ }^{56}$

\section{Results}

Pristine graphite electrodes.-As a first step, we investigate the effect of transition metal ions on the electrolyte decomposition reactions of pristine graphite electrodes, i.e., when no SEI is present. This represents the situation in commercial Li-ion cells prior to battery formation, where dissolved transition metals are observed upon electrolyte storage of the pristine materials, ${ }^{26}$ likely formed by the reaction of cathode active materials with $\mathrm{HF}$, which is present in commercial $\mathrm{LiPF}_{6}$ based electrolytes at the level of several tens of ppm, or at even higher concentration if cell components are dried improperly. ${ }^{57,58}$ As ethylene carbonate (EC) is reduced to mostly lithium ethylene dicarbonate (LEDC) and $\mathrm{C}_{2} \mathrm{H}_{4},{ }^{51,59-62}$ so that the latter is the main gaseous product during graphite SEI formation in EC-based electrolytes, ${ }^{52,55,63}$ we first focus on $\mathrm{C}_{2} \mathrm{H}_{4}$ as a marker of the reductive decomposition of EC. Figure 1 shows the current density (a) and the integral $\mathrm{C}_{2} \mathrm{H}_{4}$ evolution (b), both normalized to the active material mass of the graphite electrode, during $4 \mathrm{CV}$ cycles of pristine graphite electrodes in $\mathrm{EC} / \mathrm{LiPF}_{6}$ without added transition metal salts, or with either $1.5 \mu \mathrm{mol} \mathrm{Mn}{ }^{2+}$ or $1.5 \mu \mathrm{mol} \mathrm{Ni}{ }^{2+}$ added as TFSI salts (equating to $\sim 140 \mu \mathrm{mol}_{\mathrm{TM}} / \mathrm{g}_{\text {Graphite }}$, which would correspond to $\sim 0.3 \mathrm{wt} \%$ dissolution of a NCM cathode active material in a balanced full-cell; for details see Experimental section).

The blue lines in Figure 1 show the baseline for the transition metal-free electrolyte. During the first cycle, a reduction peak current around $0.5 \mathrm{~V}$ vs. $\mathrm{Li}^{+} / \mathrm{Li}$ appears (Figure 1a), alongside with the evolution of $\sim 80 \mu \mathrm{mol} / \mathrm{g} \mathrm{C}_{2} \mathrm{H}_{4}$ (Figure $1 \mathrm{~b}$ ), in good quantitative agreement with the $\sim 10 \mu \mathrm{mol} / \mathrm{m}^{2}{ }_{\text {BET }} \mathrm{C}_{2} \mathrm{H}_{4}$ found in earlier studies on the same graphite (BET: $7 \mathrm{~m}^{2} / \mathrm{g}$ ). ${ }^{12,55}$ In the following cycles, the $\mathrm{C}_{2} \mathrm{H}_{4}$ evolution stops (as indicated by the constant concentration), also consistent with our previous reports. ${ }^{12,52,55,64}$ When $1.5 \mu \mathrm{mol}$ $\mathrm{Ni}(\mathrm{TFSI})_{2}$ are added to the electrolyte, an additional reduction feature in the first cycle, starting at $\sim 2.5 \mathrm{~V}$ vs. $\mathrm{Li}^{+} / \mathrm{Li}$, can be seen in the current response (see green line in Figure 1a). For the Ni-containing electrolyte, $\mathrm{C}_{2} \mathrm{H}_{4}$ is evolved at much less negative potentials in the first reduction cycle (at $\sim 1.6 \mathrm{~V}$ vs. $\mathrm{Li}^{+} / \mathrm{Li}$ ) and at higher amounts $(112 \mu \mathrm{mol} / \mathrm{g}$, see green lines in Figure $1 \mathrm{~b}$; for details please also refer 


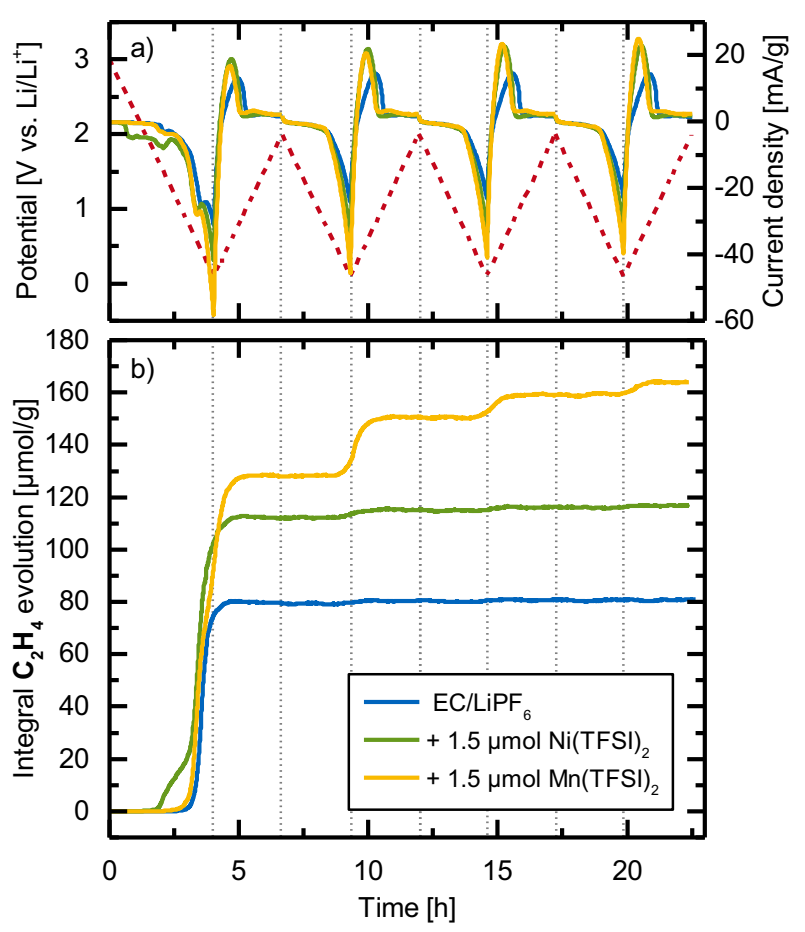

Figure 1. Currents and ethylene evolution during the first 4 voltammetric cycles of pristine graphite electrodes in $\mathrm{EC} / 1.5 \mathrm{M} \mathrm{LiPF}_{6}$ electrolyte without added metal salts (blue lines), with $1.5 \mu \mathrm{mol} \mathrm{Ni(TFSI})_{2}$ (green lines), or with $1.5 \mu \mathrm{mol} \mathrm{Mn(TFSI})_{2}$ (yellow lines). a) Currents normalized to graphite mass (solid lines) and potential (red dashed line); b) integral ethylene evolution normalized to graphite mass. The voltammetric cycles were conducted at $0.2 \mathrm{mV} / \mathrm{s}$ between $0.1-2.0 \mathrm{~V} \mathrm{vs.} \mathrm{Li}^{+} / \mathrm{Li}$, starting the first reductive scan from OCV $(\sim 3 \mathrm{~V}$ vs. $\left.\mathrm{Li}^{+} / \mathrm{Li}\right)$.

to Figure 5), which increases slightly up to $117 \mu \mathrm{mol} / \mathrm{g}$ by the end of 4 charge/discharge cycles. As previous studies showed an identical gassing behavior of graphite electrodes cycled in either transition metal-free LiTFSI ${ }^{64}$ or $\mathrm{LiPF}_{6}{ }^{52,55}$ based electrolytes, the effect of the TFSI $^{-}$anions on gassing should be negligible, so that the changes upon the addition of $\mathrm{Ni}(\mathrm{TFSI})_{2}$ must be due to the presence of $\mathrm{Ni}^{2+}$. The addition of $1.5 \mu \mathrm{mol} \mathrm{Mn}(\mathrm{TFSI})_{2}$ (see yellow lines in Figure 1) leads to the highest $\mathrm{C}_{2} \mathrm{H}_{4}$ evolution in the 1 st cycle, namely $128 \mu \mathrm{mol} / \mathrm{g}$. Quite strikingly, with $\mathrm{Mn}^{2+}$, a distinct $\mathrm{C}_{2} \mathrm{H}_{4}$ evolution is seen in each cycle, accumulating to $164 \mu \mathrm{mol} / \mathrm{g} \mathrm{C}_{2} \mathrm{H}_{4}$ after 4 charge/discharge cycles. A more detailed discussion on the potentials at which the $1^{\text {st }}$ cycle reduction current peaks and the onset of $\mathrm{C}_{2} \mathrm{H}_{4}$ evolution occur can be found in the Discussion section (see Figure 5).

While $\mathrm{C}_{2} \mathrm{H}_{4}$ is the main gaseous product from $\mathrm{EC}$ reduction, $\mathrm{H}_{2},{ }^{12,51} \mathrm{CO},{ }^{55,62,65,66}$ and $\mathrm{CO}_{2}{ }^{63,65}$ are also commonly observed during the formation of graphite in carbonate-based electrolytes. The total quantities of $\mathrm{C}_{2} \mathrm{H}_{4}, \mathrm{H}_{2}$, and $\mathrm{CO}$ after 4 cycles are shown in Figure 2a. After 4 cycles in the TM-free electrolyte (blue bars in Figure 2a), $48 \mu \mathrm{mol} / \mathrm{g} \mathrm{H}_{2}$ and $20 \mu \mathrm{mol} / \mathrm{g} \mathrm{CO}$ have been evolved in addition to the $81 \mu \mathrm{mol} / \mathrm{g}$ of $\mathrm{C}_{2} \mathrm{H}_{4}$. For $\mathrm{Ni}^{2+}$ - and $\mathrm{Mn}^{2+}$-containing electrolytes (green and yellow bars in Figure 2a), the concentration of $\mathrm{CO}$ is almost twice as high as in the TM-free electrolyte $(36$ and $43 \mu \mathrm{mol} / \mathrm{g}$, respectively). In contrast, the amount of $\mathrm{H}_{2}$ is similar in the absence and presence of dissolved transition metals (TM-free: $48 \mu \mathrm{mol} / \mathrm{g}$; with $\mathrm{Ni}^{2+}: 47 \mu \mathrm{mol} / \mathrm{g} ; \mathrm{Mn}^{2+}: 63 \mu \mathrm{mol} / \mathrm{g}$ ). While $\mathrm{H}_{2}$ is the reduction product of trace water and/or HF in the electrolyte, ${ }^{57,64} \mathrm{CO}$ evolution has been ascribed to a direct 2-electron reduction of EC, ${ }^{65-68}$ a minor pathway for EC reduction. Note that we also see small quantities of $\mathrm{CO}_{2}(<20 \mu \mathrm{mol} / \mathrm{g})$ during the first cycle of all experiments, which is however consumed during the subsequent cycles and thus does not appear in Figure 2.

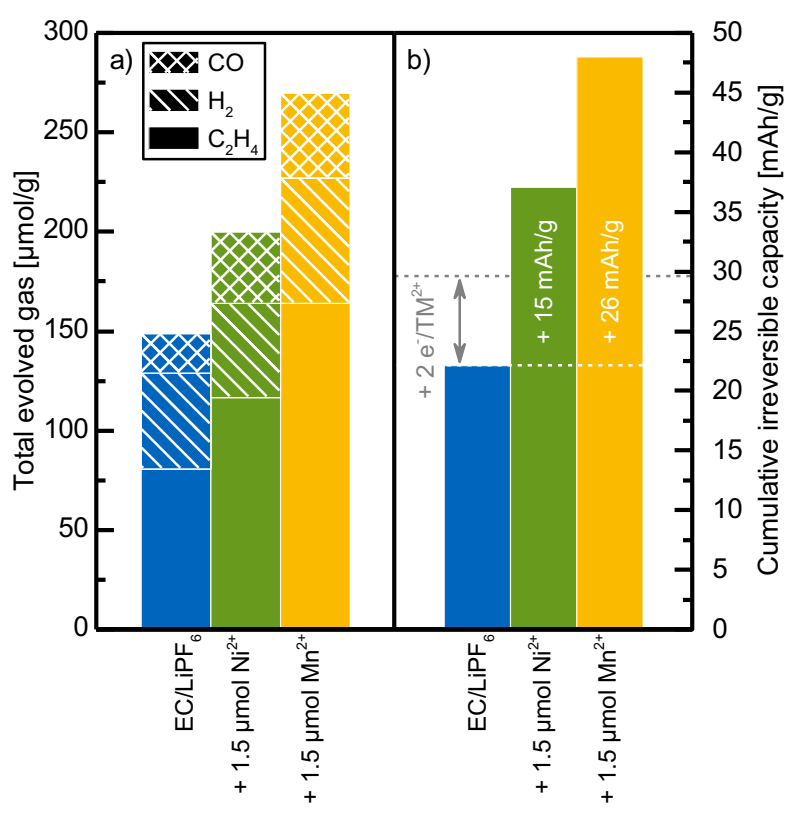

Figure 2. Total evolved gas and cumulative irreversible capacity (both normalized to graphite mass) over the first 4 cycles of the pristine graphite electrodes shown in Figure 1, i.e., in EC/1.5 $\mathrm{M} \mathrm{LiPF}_{6}$ electrolyte without added metal salts (blue bars), with $1.5 \mu \mathrm{mol} \mathrm{Ni(TFSI})_{2}$ (green bars), or with $1.5 \mu \mathrm{mol}$ $\mathrm{Mn}(\mathrm{TFSI})_{2}$ (yellow bars). a) Total evolved $\mathrm{C}_{2} \mathrm{H}_{4}$ (solid bars), $\mathrm{H}_{2}$ (dashed bars), and $\mathrm{CO}$ (squared bars). b) Cumulative irreversible capacity, with the gray arrow indicating the theoretical charge for 2-electron reduction of the added $\mathrm{Ni}^{2+}$ or $\mathrm{Mn}^{2+}$ ions.

Figure $2 b$ shows the cumulative irreversible capacities (i.e., the summed-up differences between lithiation and delithiation capacity) after the $4 \mathrm{CV}$ cycles depicted in Figure 1a. For the TM-free electrolyte (blue bars), the cumulative irreversible capacity is $22 \mathrm{mAh} / \mathrm{g}$, which fits well to the expected formation losses of $7-10 \%$ of the initial capacity for graphite electrodes. ${ }^{9}$ The cumulative irreversible capacity over 4 cycles in an electrolyte with $\mathrm{Ni}^{2+}$ ions (green bars) is significantly higher $(37 \mathrm{mAh} / \mathrm{g})$, but still smaller than that of the $\mathrm{Mn}^{2+}$-containing electrolyte $(48 \mathrm{mAh} / \mathrm{g}$ ), which fits to the observation that the latter also exhibits the highest amount of evolved gas (Figure 2a). Note that the additional cumulative irreversible capacity losses in the Ni-containing and the Mn-containing electrolytes $(+15 \mathrm{mAh} / \mathrm{g}$ and $+26 \mathrm{mAh} / \mathrm{g}$, respectively) substantially exceed the capacity of $\sim 7.5 \mathrm{mAh} / \mathrm{g}$ required for a simple 2-electron reduction of the $\mathrm{TM}^{2+}$ ions (see horizontal gray dashed line in Figure 2b; based on the added salt concentration of $0.85 \mu \mathrm{mol} / \mathrm{cm}^{2}$ and the graphite loding of $6.1 \mathrm{mg} / \mathrm{cm}^{2}$ ), namely by a factor of $\sim 2$ for $\mathrm{Ni}^{2+}$ and of $\sim 3.5$ for $\mathrm{Mn}^{2+}$. This clearly indicates that at least the difference between the measured cumulative irreversible capacity and the theoretical charge for the TM ion reduction to the metal (i.e., the $\sim 7.5 \mathrm{mAh} / \mathrm{g}$ ) must have gone into the irreversible reduction of the electrolyte.

The results from Figure 1 and Figure 2 show that in the presence of TM ions, especially $\mathrm{Mn}^{2+}$, strong additional electrolyte reduction takes place, consuming lithium and generating gas. As the composition of the evolved gas is comparable for all electrolytes, the fundamental reactions during SEI formation in TM-free and TM-containing electrolytes are apparently very similar. Moreover, the results demonstrate that manganese species continuously decompose electrolyte, whereas the activity of nickel species toward electrolyte reduction subsides much quicker.

Preformed graphite electrodes.-In commercial cells, the majority of transition metal dissolution occurs typically during cycling at high temperatures or voltages over extended periods of time. In this case, the SEI is already formed when the transition metal ions reach the anode. Therefore, we also investigate the effect of $\mathrm{Ni}^{2+}$ and 


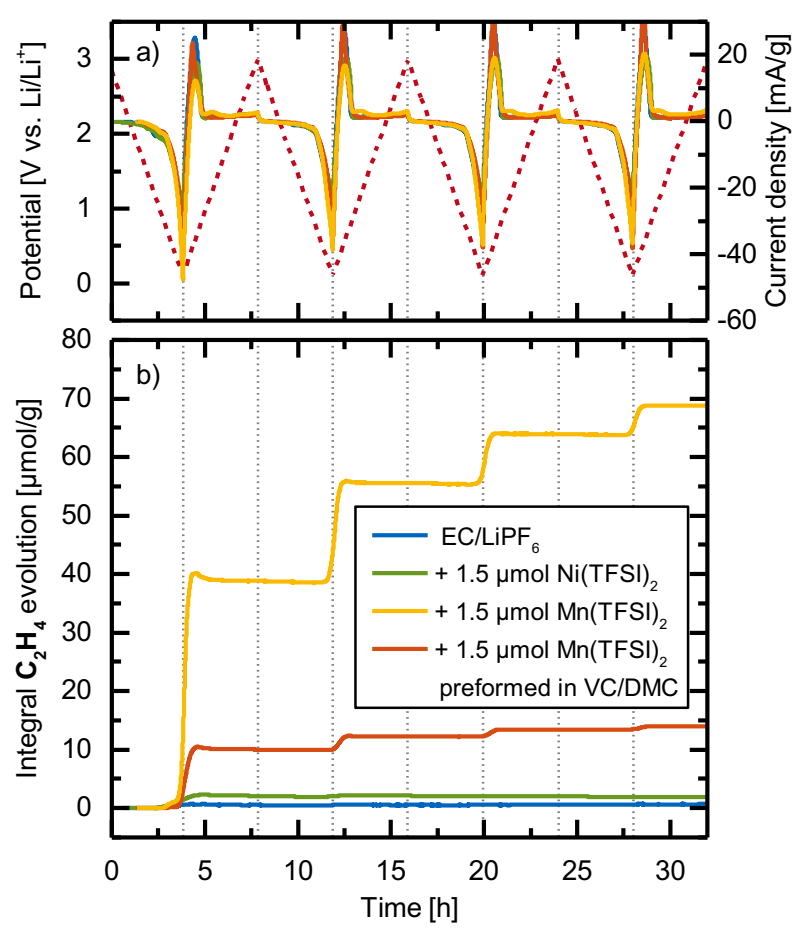

Figure 3. a) Currents and b) ethylene evolution, normalized to graphite mass, during the first 4 voltammetric cycles of preformed graphite electrodes in $\mathrm{EC} / 1.5 \mathrm{M} \mathrm{LiPF}_{6}$ electrolyte with/without added metal salts. Preformation was done with TM-free electrolyte in a separate cell vs. an LFP cathode ( 2 cycles at $\mathrm{C} / 8$ ), using two different preformation electrolytes: i) $\mathrm{EC} / 1.5 \mathrm{M} \mathrm{LiPF}_{6}$ for the OEMS experiments in TM-free electrolyte (blue) or electrolyte with either $1.5 \mu \mathrm{mol} \mathrm{Ni(TFSI})_{2}$ (green lines) or $\left.1.5 \mu \mathrm{mol} \mathrm{Mn(TFSI}\right)_{2}$ (yellow); ii) $\mathrm{DMC} / 1.5 \mathrm{M} \mathrm{LiPF}_{6}+2 \% \mathrm{VC}$ for the OEMS experiment in electrolyte with $1.5 \mu \mathrm{mol} \mathrm{Mn}(\mathrm{TFSI})_{2}$ (orange). The voltammetric cycles at $0.2 \mathrm{mV} / \mathrm{s}$ were done between $0.1-3.0 \mathrm{~V}$ vs. $\mathrm{Li}^{+} / \mathrm{Li}$, starting from OCV $\left(\sim 2.9 \mathrm{~V}\right.$ vs. $\left.\mathrm{Li}^{+} / \mathrm{Li}\right)$.

$\mathrm{Mn}^{2+}$ ions on preformed graphite electrodes. The SEI formation was achieved by pre-cycling ( 2 cycles at $\mathrm{C} / 8$ ) the graphite electrodes in a 1-compartment OEMS cell with capacitively oversized LFP counter electrodes in a TM-free EC $+1.5 \mathrm{M} \mathrm{LiPF}_{6}$ electrolyte; the resulting SEI is known to consist mostly of LEDC and LiF, with only traces of $\mathrm{Li}_{2} \mathrm{CO}_{3}$ present. ${ }^{60}$ Afterwards, the cells were deep-discharged to a cell voltage of $0.3 \mathrm{~V}_{\text {cell }}$ (corresponding to a graphite electrode potential of $\sim 2.9 \mathrm{~V}$ vs. $\mathrm{Li}^{+} / \mathrm{Li}$ ), and the graphite electrodes were then transferred without further washing into the 2-compartment OEMS cell in an Ar-filled glove box. The discharge capacity over these first two formation cycles was $350-355 \mathrm{mAh} / \mathrm{g}$, while the irreversible capacity accumulated to $25-27 \mathrm{mAh} / \mathrm{g}$.

Figure 3 shows the current density (a) and the integral $\mathrm{C}_{2} \mathrm{H}_{4}$ evolution (b) during $4 \mathrm{CV}$ cycles of the thus preformed graphite electrodes in electrolytes containing $1.5 \mu \mathrm{mol} \mathrm{Mn}^{2+}$ (yellow lines), $1.5 \mu \mathrm{mol}$ $\mathrm{Ni}^{2+}$ (green lines) or no transition metal ions (blue lines). As one would expect, the TM-free electrolyte baseline for the preformed graphite electrode does no longer show the EC reduction current peak at $\sim 0.5 \mathrm{~V} \mathrm{vs} . \mathrm{Li}^{+} / \mathrm{Li}$, consistent with the observation that only traces of $\mathrm{C}_{2} \mathrm{H}_{4}(\sim 0.5 \mu \mathrm{mol} / \mathrm{g})$ are evolved compared to the $\sim 80 \mu \mathrm{mol} / \mathrm{g} \mathrm{C}_{2} \mathrm{H}_{4}$ evolved on a pristine graphite electrode (blue line in Figure 1b). Hence, the passivating properties of the SEI preformed in $\mathrm{EC} / \mathrm{LiPF}_{6}$ remained largely intact after transferring the preformed graphite electrode into the 2-compartment OEMS cell. On the other hand, with $1.5 \mu \mathrm{mol} \mathrm{Ni}{ }^{2+}$ in the electrolyte, $\sim 2 \mu \mathrm{mol} / \mathrm{g} \mathrm{C}_{2} \mathrm{H}_{4}$ are evolved during the first cycle (see green lines in Figure 3b), without any further $\mathrm{C}_{2} \mathrm{H}_{4}$ evolution in the subsequent cycles. If we compare the additional $\mathrm{C}_{2} \mathrm{H}_{4}$ evolution over 4 charge/discharge cycles induced by the presence of $\mathrm{Ni}^{2+}$ in the electrolyte on pristine graphite electrodes $(\sim 36 \mu \mathrm{mol} / \mathrm{g}$; green line in Figure $1 \mathrm{~b})$ vs. on preformed graphite electrodes $(\sim 2 \mu \mathrm{mol} / \mathrm{g}$; green line in Figure 3b), it becomes apparent that the effect of $\mathrm{Ni}^{2+}$ in the electrolyte is greatly suppressed by the presence of an SEI. Besides,

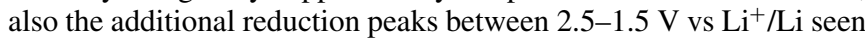
in Figure 1a (green line) are no longer observed on the preformed graphite electrode (green line in Figure 3a). This suggests that nickel ions released into the electrolyte from cathode active materials over the course of extended charge/discharge cycling should hardly compromise the stability of the SEI, and thus should only have a very minor negative impact on the active lithium inventory of the cell.

On the contrary, the addition of $1.5 \mu \mathrm{mol} \mathrm{Mn}{ }^{2+}$ to a graphite electrode preformed in $\mathrm{EC} \mathrm{LiPF}_{6}$ (yellow lines in Figure 3) leads to a $\sim 20$-fold higher $\mathrm{C}_{2} \mathrm{H}_{4}$ evolution in the first cycle $(39 \mu \mathrm{mol} / \mathrm{g}) \mathrm{com}$ pared to $\mathrm{Ni}^{2+}$, which continues in subsequent cycles, accumulating to a total amount of evolved $\mathrm{C}_{2} \mathrm{H}_{4}$ of $\sim 69 \mu \mathrm{mol} / \mathrm{g}$ after 4 cycles. This amounts to $\sim 80 \%$ of the additional $\mathrm{C}_{2} \mathrm{H}_{4}$ evolved on a pristine graphite electrode upon the addition of $\mathrm{Mn}^{2+}$ ions to the electrolyte (see difference between blue and yellow lines in Figure 1), which therefore implies that even if the SEI is formed in an $\mathrm{Mn}^{2+}$-free electrolyte, it is not able to suppress the detrimental electrolyte reduction reactions triggered by $\mathrm{Mn}^{2+}$ ions. In summary, while an SEI preformed in $\mathrm{EC} / \mathrm{LiPF}_{6}$ almost completely suppresses the negative effect of $\mathrm{Ni}^{2+}$ ions on electrolyte decomposition, it is not very effective in the presence of $\mathrm{Mn}^{2+}$ ions.

To better understand the effect of the SEI on the reactions caused by $\mathrm{Mn}^{2+}$ ions, we used the same graphite preformation procedure, but replaced the electrolyte for formation with $\mathrm{DMC} / \mathrm{LiPF}_{6}+2 \mathrm{wt} \%$ vinylene carbonate (VC). In this case, the SEI formed with VC consists mainly of poly(VC) and $\mathrm{Li}_{2} \mathrm{CO}_{3},{ }^{69}$ and has been reported to partially mitigate the poor coulombic efficiency ${ }^{70}$ and impedance growth ${ }^{35}$ caused by transition metal ions; furthermore, due to the absence of EC, no LEDC is being formed. ${ }^{62}$ After formation ( 2 cycles at $\mathrm{C} / 8$, yielding a cumulative irreversible capacity of $\sim 31 \mathrm{mAh} / \mathrm{g}$ ), the electrode was rinsed with pure DMC to remove any remaining $\mathrm{VC}$, and was transferred into the 2-compartment OEMS cell. The orange lines in Figure 3 show the current profile and the $\mathrm{C}_{2} \mathrm{H}_{4}$ evolution of the VC-preformed graphite electrode cycled in $\mathrm{EC}_{2} \mathrm{LiPF}_{6}+1.5 \mu \mathrm{mol}$ $\mathrm{Mn}^{2+}$ electrolyte. Although $\mathrm{C}_{2} \mathrm{H}_{4}$ is still evolved throughout all 4 cycles, its overall amount after 4 cycles is only $\sim 20 \%$ of that obtained with the graphite electrode preformed in $\mathrm{EC} / \mathrm{LiPF}_{6}$ electrolyte (viz., $14 \mu \mathrm{mol} / \mathrm{g}$ vs. $69 \mu \mathrm{mol} / \mathrm{g}$, comparing the orange vs. the yellow lines in Figure 3)

Figure $4 \mathrm{a}$ shows the evolution of $\mathrm{C}_{2} \mathrm{H}_{4}, \mathrm{H}_{2}$, and $\mathrm{CO}$ after 4 cycles from all the experiments shown in Figure 3. The gas evolution in the TM-free electrolyte (blue bar) is limited to low amounts of $\mathrm{H}_{2}$ ( $\sim 7 \mu \mathrm{mol} / \mathrm{g}$ ), probably from the reduction of newly introduced $\mathrm{HF}$ or trace water of the fresh electrolyte, its reduction largely perhibited by the preformed SEI. All of the TM-containing electrolytes evolve more $\mathrm{H}_{2}\left(\sim 23 \mu \mathrm{mol} / \mathrm{g}\left(\mathrm{Ni}^{2+}\right)\right.$ and $\sim 32 \mu \mathrm{mol} / \mathrm{g}\left(\mathrm{Mn}^{2+}\right)$ for electrodes preformed in $\mathrm{EC} / \mathrm{LiPF}_{6} ; \sim 28 \mu \mathrm{mol} / \mathrm{g}\left(\mathrm{Mn}^{2+}\right)$ for electrodes preformed in $\left.\mathrm{DMC} / 2 \% \mathrm{VC} / \mathrm{LiPF}_{6}\right)$, suggesting that $\mathrm{TM}$ ions can catalyze the reduction of protic species, which is normally hindered by the SEI. ${ }^{64}$ While for the electrode cycled in $\mathrm{Ni}^{2+}$-containing electrolyte (green bars), only traces of $\mathrm{CO}(\sim 1 \mu \mathrm{mol} / \mathrm{g})$ are observed, the $\mathrm{Mn}^{2+}$-containing electrolyte evolves $\sim 32 \mu \mathrm{mol} / \mathrm{g} \mathrm{CO}$ after 4 cycles if preformed in $\mathrm{EC} / \mathrm{LiPF}_{6}$ (yellow bars), lowered to $\sim 12 \mu \mathrm{mol} / \mathrm{g} \mathrm{CO}$ if preformed in

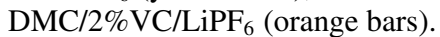

The corresponding cumulative irreversible capacity for the preformed electrodes after 4 cycles is displayed in Figure $4 \mathrm{~b}$. As expected from the gas evolution, the electrode cycled in the TM-free electrolyte (blue bars) shows the lowest irreversible capacity ( $\sim 6 \mathrm{mAh} / \mathrm{g})$. For the $\mathrm{Ni}^{2+}$-containing electrolyte (green bars), the cumulative irreversible capacity is $\sim 13 \mathrm{mAh} / \mathrm{g}$, so that the excess irreversible loss $(\sim 7 \mathrm{mAh} / \mathrm{g})$ is rather close to the theoretical capacity required for the 2-electron reduction of all $\mathrm{Ni}^{2+}$ ions $(\sim 7.5 \mathrm{mAh} / \mathrm{g}$, see above). The highest irreversible capacity $(\sim 29 \mathrm{mAh} / \mathrm{g})$ comes from the electrode preformed in EC and cycled in $\mathrm{Mn}^{2+}$-containing electrolyte (yellow bars). The excess irreversible capacity measured for the $\mathrm{EC} / \mathrm{LiPF}_{6}$ preformed electrode caused by $\mathrm{Mn}^{2+}(\sim 23 \mathrm{mAh} / \mathrm{g}$ more than in the TM-free electrolyte) is comparable to the additional irreversible capacity in 


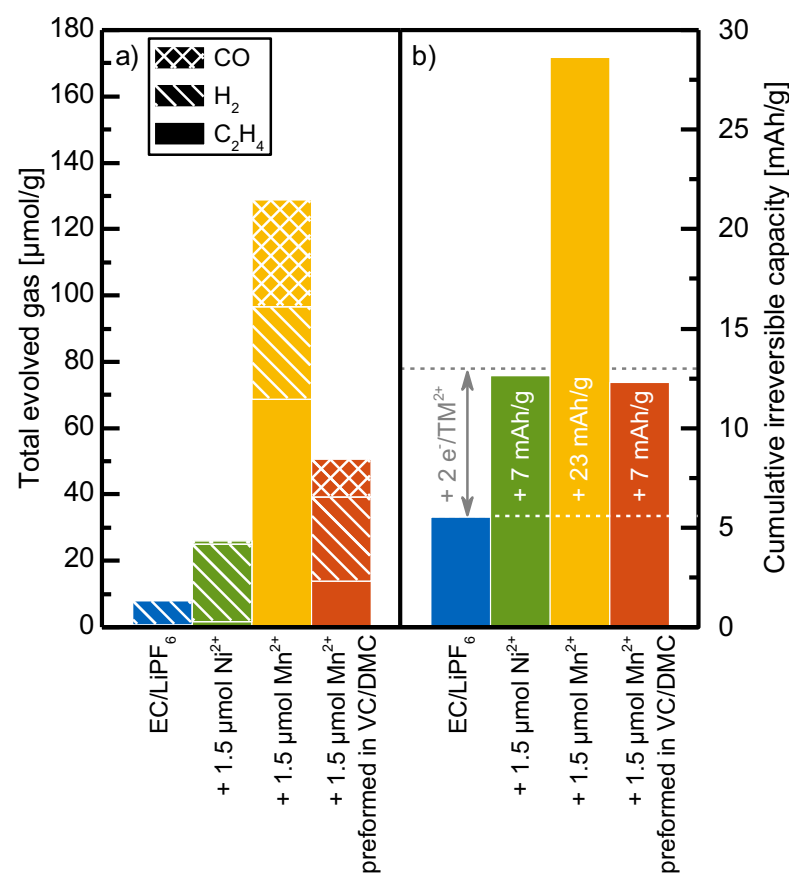

Figure 4. Total evolved gas and cumulative irreversible capacity (both normalized to graphite mass) over the first 4 cycles of the preformed graphite electrodes in $\mathrm{EC} /+1.5 \mathrm{M} \mathrm{LiPF}_{6}$ with/without added metal salts, as shown in Figure 3. a) Total evolved $\mathrm{C}_{2} \mathrm{H}_{4}$ (solid bars), $\mathrm{H}_{2}$ (dashed bars), and $\mathrm{CO}$ (squared bars). b) Cumulative irreversible capacity, with the gray arrow indicating the theoretical charge for 2-electron reduction of the added $\mathrm{Ni}^{2+}$ or $\mathrm{Mn}^{2+}$ ions. Preformation was done in two different electrolytes: i) EC/1.5 M $\mathrm{LiPF}_{6}$ for the OEMS experiments in TM-free electrolyte (blue) or electrolyte with either $1.5 \mu \mathrm{mol} \mathrm{Ni(TFSI})_{2}$ (green lines) or $\left.1.5 \mu \mathrm{mol} \mathrm{Mn(TFSI}\right)_{2}$ (yellow); ii) $\mathrm{DMC} / 1.5 \mathrm{M} \mathrm{LiPF}_{6}+2 \% \mathrm{VC}$ for the OEMS experiment in electrolyte with $1.5 \mu \mathrm{mol} \mathrm{Mn(TFSI})_{2}$ (orange).

the experiment with pristine electrodes $(\sim 26 \mathrm{mAh} / \mathrm{g}$, see yellow bars in Figure 2b), in agreement with the similar additional total gas evolution $\left(\mathrm{C}_{2} \mathrm{H}_{4}+\mathrm{H}_{2}+\mathrm{CO}\right.$ with respect to the TM-free electrolyte) of $\sim 120 \mu \mathrm{mol} / \mathrm{g}$ on preformed electrodes (see yellow bars in Figure 4a) and $\sim 121 \mu \mathrm{mol} / \mathrm{g}$ on pristine electrodes (see yellow bars in Figure 2a). On the contrary, the electrode preformed in $\mathrm{DMC}^{2} \mathrm{LiPF}_{6}+$ $2 \% \mathrm{VC}$ and cycled in an electrolyte with $\mathrm{Mn}^{2+}$ ions (orange bars in Figure $4 \mathrm{~b}$ ) shows a largely reduced irreversible capacity that is only $\sim 7 \mathrm{mAh} / \mathrm{g}$ higher compared to the $\sim 6 \mathrm{mAh} / \mathrm{g}$ obtained in the TM-free electrolyte, and thus this difference is very close again to the theoretical capacity required for the 2-electron reduction of all $\mathrm{Mn}^{2+}$ ions ( $7.5 \mathrm{mAh} / \mathrm{g}$, see above). While this additional capacity found for $\mathrm{DMC} / \mathrm{LiPF}_{6}+2 \% \mathrm{VC}$ preformed graphite in $\mathrm{Mn}^{2+}$-containing electrolyte is identical to that for $\mathrm{Ni}^{2+}$-containing electrolyte for $\mathrm{EC} / \mathrm{LiPF}_{6}$ preformed graphite (compare orange vs. green bars in Figure 4b), the additional amount of gas produced in the presence of $\mathrm{Mn}^{2+}$ ions is substantially larger $(\sim 44 \mu \mathrm{mol} / \mathrm{g}$ vs. $\sim 16 \mu \mathrm{mol} / \mathrm{g}$; compare orange vs. green bars in Figure 4a) compared to $\mathrm{Ni}^{2+}$, suggesting that $\mathrm{Mn}^{2+}$ ions more effectively catalyze SEI and/or solvent reduction.

The results of Figure 3 and Figure 4 show that the activity of $\mathrm{Ni}^{2+}$ ions toward electrolyte reduction is suppressed by an EC-derived SEI, but that this SEI does not lead to significantly less side reactions for a $\mathrm{Mn}^{2+}$-containing electrolyte. Hence, the dissolution of manganese will be far more detrimental toward long-term cell performance compared to that of nickel, which has previously been observed by Gilbert et al. ${ }^{7}$ and Jung et al. ${ }^{5}$ However, additives like VC can help to mitigate the detrimental effect of manganese, as apparently the SEI composition plays a crucial role on the reactivity of manganese toward electrolyte reduction.

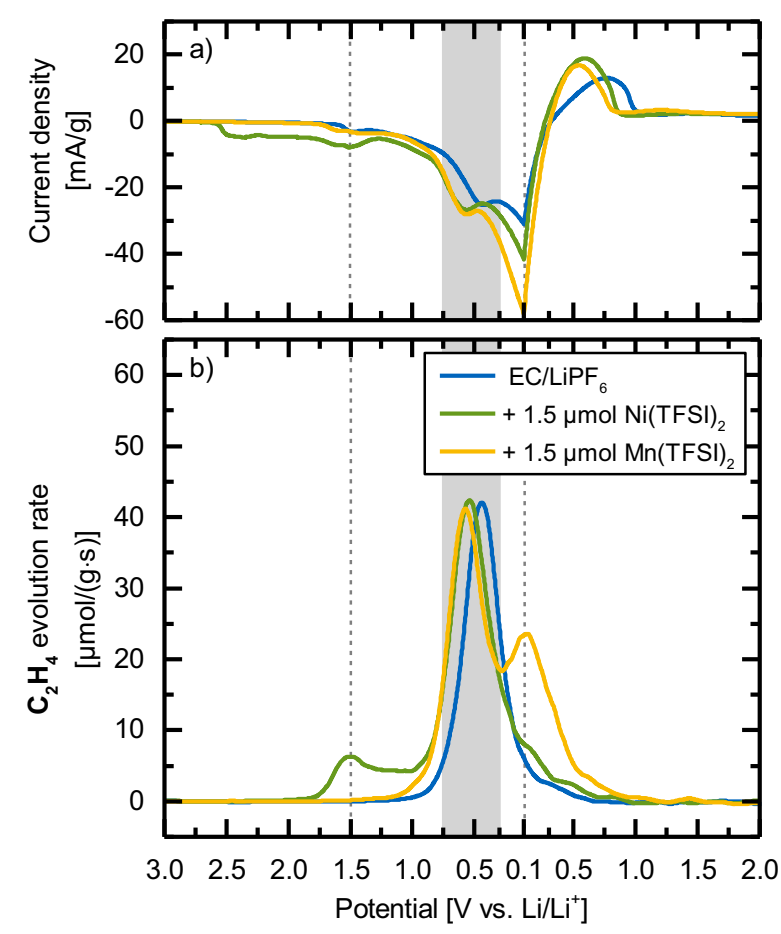

Figure 5. Currents and ethylene evolution rate during the first voltammetric cycle of pristine graphite electrodes in $\mathrm{EC} / 1.5 \mathrm{M} \mathrm{LiPF}_{6}$ electrolyte without added metal salts (blue lines), with $1.5 \mu \mathrm{mol} \mathrm{Ni(TFSI})_{2}$ (green lines), or with $1.5 \mu \mathrm{mol} \mathrm{Mn}$ (TFSI) 2 (yellow lines). a) Currents normalized to graphite mass (solid lines) and potential (red dashed line); b) integral ethylene evolution normalized to graphite mass. The data are extracted from Figure 1.

\section{Discussion}

In order to obtain further insights into the effect of dissolved transition metals on the formation, the passivating properties, and the stability of the SEI on graphite electrodes, we will initially examine the very first voltammetric reduction and oxidation cycle on a pristine graphite electrode. Figure 5 magnifies the current density and plots the $\mathrm{C}_{2} \mathrm{H}_{4}$ evolution rate (obtained by taking the derivative of the integral OEMS signals) vs. the graphite potential for the first voltammetric cycle shown in Figure 1b. For the TM-free electrolyte (see blue lines in Figures $5 \mathrm{a}$ and $5 \mathrm{~b}$ ), the first main reduction peak is observed at $\sim 0.5 \mathrm{~V} \mathrm{vs} . \mathrm{Li}^{+} / \mathrm{Li}$, which coincides with a maximum in ethylene evolution rate (see gray-shaded area in Figure 5). This peak appears for all three electrolytes and is ascribed to the reduction of EC to lithium ethylene dicarbonate (LEDC) and $\mathrm{C}_{2} \mathrm{H}_{4}$ on graphite. ${ }^{51,52,55,59-63}$

The electrolyte containing $1.5 \mu \mathrm{mol} \mathrm{Ni}{ }^{2+}$ ions (green lines in Figure 5) shows an additional reduction current already at $\sim 2.5 \mathrm{~V}$ vs. $\mathrm{Li}^{+} / \mathrm{Li}$, merging into a second small reduction current peak at $\sim 1.5 \mathrm{~V}$ vs. $\mathrm{Li}^{+} / \mathrm{Li}$ that is accompanied by a first peak in the $\mathrm{C}_{2} \mathrm{H}_{4}$ evolution rate. Jung et al..$^{5}$ observed the reduction of $\mathrm{Ni}^{2+}$ in a carbonate-based electrolyte at $\sim 2.22 \mathrm{~V} \mathrm{vs.} \mathrm{Li}^{+} / \mathrm{Li}$, so that we ascribe the first reduction peak in the Ni-containing electrolyte at $\sim 2.5 \mathrm{~V} \mathrm{vs.} \mathrm{Li}^{+} / \mathrm{Li}$ (green line in Figure 5a) to the onset of $\mathrm{Ni}^{2+}$ reduction. By up-integrating the current density difference between the Ni-containing and the TMfree electrolyte during this initial part of the first reduction scan, it becomes apparent that the $\sim 7.5 \mathrm{mAh} / \mathrm{g}$ needed for the reduction of $\mathrm{Ni}^{2+}$ to $\mathrm{Ni}^{0}$ are only reached at $\sim 1.4 \mathrm{~V}$ vs. $\mathrm{Li}^{+} / \mathrm{Li}$, which suggests that also the second peak around $1.5 \mathrm{~V}$ vs. $\mathrm{Li}^{+} / \mathrm{Li}$ belongs to the reduction of $\mathrm{Ni}^{2+}$. The concurrent $\mathrm{C}_{2} \mathrm{H}_{4}$ evolution initiating at below $\sim 1.8 \mathrm{~V} \mathrm{vs} . \mathrm{Li}^{+} / \mathrm{Li}$ is likely related to a reduction of $\mathrm{EC}$ on the nascent $\mathrm{Ni}^{0}$ surface, which occurs apparently at higher potentials than the EC reduction on the graphite surface in $\mathrm{TM}$-free $\mathrm{EC} / \mathrm{LiPF}_{6}$ electrolyte (blue line in Figure $5 b$ ), initiating at $\sim 0.9 \mathrm{~V}$ vs. $\mathrm{Li}^{+} / \mathrm{Li}$ (the same onset potential for $\mathrm{C}_{2} \mathrm{H}_{4}$ formation was observed for EC/EMC (3/7) with $1 \mathrm{M} \mathrm{LiPF}_{6}{ }^{52}$ or $\left.1 \mathrm{M} \mathrm{LiTFSI}\right){ }^{64}$ Interestingly, after the first two 
reduction peaks (i.e., at $1.25 \mathrm{~V}$ vs. $\mathrm{Li}^{+} / \mathrm{Li}$ ), the integrated current accounts to $\sim 7.9 \mathrm{mAh} / \mathrm{g}$, whereas the charge required for the twoelectron reduction of the formed $\mathrm{C}_{2} \mathrm{H}_{4}(11.8 \mu \mathrm{mol} / \mathrm{g} \equiv 0.63 \mathrm{mAh} / \mathrm{g})$ and $\mathrm{CO}(9.3 \mu \mathrm{mol} / \mathrm{g} \equiv 0.50 \mathrm{mAh} / \mathrm{g})$ together with the reduction of $\mathrm{Ni}^{2+}$ to $\mathrm{Ni}^{0}(7.5 \mathrm{mAh} / \mathrm{g})$ would require a total charge of $\sim 8.6 \mathrm{mAh} / \mathrm{g}$. This suggests that some of the electrolyte must have been reduced chemically rather than electrochemically, possibly via the re-oxidation of $\mathrm{Ni}^{0}$ back to $\mathrm{Ni}^{2+}$ in a similar mechanism as suggested for manganese. ${ }^{33,39}$

When $\mathrm{Mn}^{2+}$ ions are added (see yellow lines in Figure 5), no additional current peak can be seen, even though the onset for $\mathrm{C}_{2} \mathrm{H}_{4}$ evolution $(\sim 1.1 \mathrm{~V})$ is shifted $\sim 0.2 \mathrm{~V}$ more positively compared the TM-free electrolyte. Since the onset for $\mathrm{Mn}^{2+}$ reduction was reported to occur at $\sim 1.29 \mathrm{~V}$ vs. $\mathrm{Li}+/ \mathrm{Li},{ }^{5}$ the more positive onset for $\mathrm{C}_{2} \mathrm{H}_{4}$ evolution in $\mathrm{Mn}^{2+}$-containing electrolyte compared to TM-free electrolyte suggests that $\mathrm{EC}$ reduction is catalyzed by $\mathrm{Mn}^{\circ}$ formed at the graphite electrode. Overall, these results with $\mathrm{Ni}^{2+}$ - and $\mathrm{Mn}^{2+}$ containing electrolyte indicate that the earlier onset of $\mathrm{C}_{2} \mathrm{H}_{4}$ evolution occurs only below the respective reduction potential of the transition metal ions, suggesting that only the reduced transition metals are active toward electrolyte reduction. Rather noteworthy in the case of $\mathrm{Mn}^{2+}$-containing electrolyte is that the $\mathrm{C}_{2} \mathrm{H}_{4}$ evolution rate increases again during the first positive-going potential scan, with a maximum at $\sim 0.1 \mathrm{~V}$ vs. $\mathrm{Li}^{+} / \mathrm{Li}$ (see gray dashed line at $0.1 \mathrm{~V}$ vs. $\mathrm{Li}^{+} / \mathrm{Li}$ in Figure 5), in stark contrast to the vanishing $\mathrm{C}_{2} \mathrm{H}_{4}$ evolution rate in TM-free or $\mathrm{Ni}_{2+}$-containing electrolyte. This is a clear evidence for the SEI decomposing properties of $\mathrm{Mn}^{2+}$ in contrast to $\mathrm{Ni}^{2+}$.

That transition metals can affect the composition and stability of the SEI on graphite was proposed, e.g., by Joshi et al., ${ }^{32}$ who added $10 \mathrm{mM}$ concentrations of each $\mathrm{Ni}^{+2}, \mathrm{Mn}^{2+}$, and $\mathrm{Co}^{2+}$ to a $\mathrm{EC} / \mathrm{DEC} / \mathrm{LiPF}_{6}$ electrolyte and found evidence that transition metal ions catalyze the decomposition of LEDC in the SEI to $\mathrm{Li}_{2} \mathrm{CO}_{3}$, presumably by the release of $\mathrm{C}_{2} \mathrm{H}_{4}, \mathrm{CO}_{2}$, and $\mathrm{O}_{2}$. Later on, Leung ${ }^{50}$ proposed that $\mathrm{Mn}^{2+}$ trapped in the SEI could decompose LEDC to alkoxides by releasing $\mathrm{CO}_{2}{ }^{-}$, which could convert to $\mathrm{CO}_{2}$ by transferring the excess electron to a solvent molecule. This is consistent with the catalytic effect of $\mathrm{Mn}^{2+}$ on SEI decomposition deduced from Figure 3 and Figure 4, where continuous electrolyte decomposition even on a preformed graphite electrode is observed in the presence of $\mathrm{Mn}^{2+}$ ions. To better understand how transition metal ions in the electrolyte affect the SEI composition on a preformed electrode (in a TM-free $\mathrm{EC} / \mathrm{LiPF}_{6}$ electrolyte according to the above described procedure), they were transferred without washing into a new cell which we assembled with a fresh separators, a capacitively oversized LFP counter electrode, and an $\mathrm{EC}^{2} \mathrm{LiPF}_{6}$ electrolyte with $1.5 \mu \mathrm{mol}$ $\mathrm{Mn}^{2+}$ ions, $1.5 \mu \mathrm{mol} \mathrm{Ni}{ }^{2+}$ ions, or without any transition metals. Subsequently, the cells were cycled between $2.0-3.45 \mathrm{~V}_{\text {cell }}$ at $\mathrm{C} / 8$ for two cycles, after which the harvested graphite electrodes were washed with DMC and then investigated by attenuated total reflection Fourier-transform infrared (ATR-FTIR) spectroscopy.

Figure 6 shows the ATR-FTIR spectra of the pristine (i.e., unused) graphite electrodes (gray spectra) as well as preformed electrodes cycled in the TM-free (blue spectra), $\mathrm{Ni}^{2+}$-containing (green spectra), or $\mathrm{Mn}^{2+}$-containing (yellow spectra) electrolyte. All spectra were normalized to have the same intensity for the PVDF peak at $1190 \mathrm{~cm}^{-1}$, marked by the gray dashed line. For the cycled electrodes, the new peaks arising at $\sim 1630 \mathrm{~cm}^{-1}$ and $1300 \mathrm{~cm}^{-1}$ can be assigned to LEDC, ${ }^{71,72}$ whereas the peak at $\sim 1750 \mathrm{~cm}^{-1}$ belongs to organic carbonate oligomers. ${ }^{52}$ While no major differences could be found between the electrodes cycled in a TM-free and in an electrolyte with $\mathrm{Ni}^{2+}$ ions, the electrode cycled in the $\mathrm{Mn}^{2+}$-containing electrolyte shows strongly pronounced peaks around $1420-1480 \mathrm{~cm}^{-1}$ (marked by the navy colored dashed lines), which is characteristic for inorganic carbonates like $\mathrm{Li}_{2} \mathrm{CO}_{3}$; for comparison, the spectra of pure $\mathrm{Li}_{2} \mathrm{CO}_{3}$ is also given in Figure 6 (navy line). Unfortunately, the $\mathrm{Li}_{2} \mathrm{CO}_{3}$ peak at $\sim 850 \mathrm{~cm}^{-1}$ coincides with a PVDF peak (see gray line in Figure 6). Nevertheless, these results indicate that a $\mathrm{Mn}^{2+}$-contaminated SEI contains more inorganic carbonates, in agreement with Joshi et al. ${ }^{32}$ It is to note that this observation also fits to the mechanism proposed

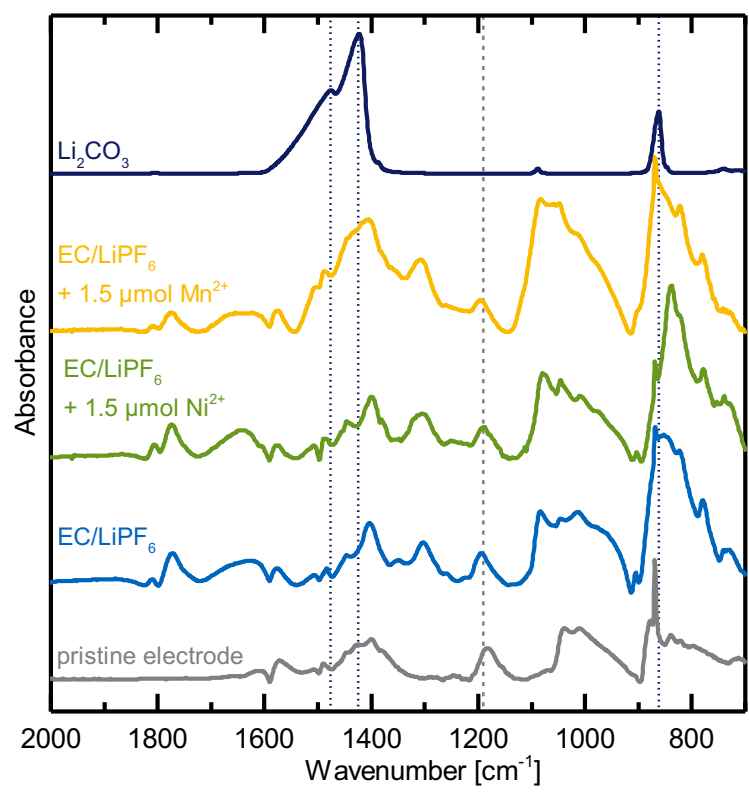

Figure 6. ATR-FTIR-spectra of a pristine graphite electrode (gray line) and of preformed graphite electrodes after two cycles at $\mathrm{C} / 8$ between $2.0-3.45 \mathrm{~V}_{\text {cell }}$ (in a cell with an LFP cathode) in different $\mathrm{EC} / 1.5 \mathrm{M} \mathrm{LiPF}_{6}$ electrolytes: i) without transition metal (blue line); ii) with $1.5 \mu \mathrm{mol} \mathrm{Ni(TFSI})_{2}$ (green line); or, iii) with $1.5 \mu \mathrm{mol} \mathrm{Mn(TFSI)} 2$ (yellow line). Preformation was done in TM-free EC/1.5 $\mathrm{M} \mathrm{LiPF}_{6}$ for two cycles at C/8; prior to ATR-FTIR analysis, the cycled electrodes were washed with DMC. The spectra were normalized to the PVDF peak at $1190 \mathrm{~cm}^{-1}$ (see gray dashed line). The reference spectrum of $\mathrm{Li}_{2} \mathrm{CO}_{3}$ is also given, with characteristic peaks marked by the navy colored dotted lines.

by Leung, ${ }^{50}$ as $\mathrm{CO}_{2}\left(\right.$ or $\mathrm{CO}_{2}{ }^{-}$) is readily reduced on graphite to form $\mathrm{Li}_{2} \mathrm{CO}_{3},{ }^{73}$ but due to the simultaneous consumption and evolution of $\mathrm{CO}_{2}$ in our closed-cell system, this process would not be traceable by OEMS

As both the reduction of EC and the decomposition of LEDC to $\mathrm{Li}_{2} \mathrm{CO}_{3}$ as proposed by Joshi et al. ${ }^{32}$ would lead to the evolution of $\mathrm{C}_{2} \mathrm{H}_{4}$, we designed an experiment where these two processes could be separated. For this, we carefully washed graphite electrodes preformed in $\mathrm{TM}$-free $\mathrm{EC}^{\mathrm{LiPF}} 6 \mathrm{Fith}_{6}$ w $\mathrm{mL} \mathrm{DMC}$, and then cycled them in the 2-compartment OEMS cell with $\mathrm{DMC} / \mathrm{LiPF}_{6}$ electrolyte containing either $1.5 \mu \mathrm{mol} \mathrm{Mn^{2+ }}$ ions or no TM ions. As the reduction of DMC generates $\mathrm{CO}$, but no $\mathrm{C}_{2} \mathrm{H}_{4},{ }^{66}$ we should now be able to differentiate between electrolyte reduction and SEI decomposition. To first test if any EC remains in the pores of the electrode after washing, we additionally soaked a graphite electrode with the $\mathrm{EC} / \mathrm{LiPF}_{6}$ electrolyte, rinsed it, and then cycled it in the TM-free $\mathrm{DMC}^{\mathrm{L}} \mathrm{LiPF}_{6}$ electrolyte. Figure 7 shows the current density (a) and the $\mathrm{C}_{2} \mathrm{H}_{4}$ evolution (b) over the course of 4 voltammetric cycles. The electrode that was stored

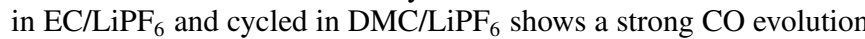
(dashed navy colored line), amounting to $\sim 148 \mu \mathrm{mol} / \mathrm{g}$ CO over 4 cycles, as no passivating SEI layer is present; these results are similar to a previous gas evolution study on $\mathrm{EMC} / \mathrm{LiPF}_{6}$ electrolytes by our group, where $\mathrm{CO}$ is the only gas evolved upon the reduction of EMC. ${ }^{55}$ However, for the EC/LiPF 6 soaked graphite electrode, $\sim 11 \mu \mathrm{mol} / \mathrm{g}$ $\mathrm{C}_{2} \mathrm{H}_{4}$ (solid navy colored line) are evolved over the 4 cycles, which originate from the remaining EC that could not be removed by the washing step (however, still a minor amount compared to the evolved $\mathrm{CO})$. In contrast, the preformed electrode that was cycled in the TMfree $\mathrm{DMC}_{\mathrm{LiPF}}$ electrolyte (superimposing blue solid and dashed lines in Figure 7) shows neither CO nor $\mathrm{C}_{2} \mathrm{H}_{4}(<0.1 \mu \mathrm{mol} / \mathrm{g})$, meaning that the SEI has not been damaged due to the washing process.

Lastly, the yellow lines in Figure 7 show the behavior of the preformed graphite electrode cycled in the $\mathrm{Mn}^{2+}$-containing $\mathrm{DMC} / \mathrm{LiPF}_{6}$ electrolyte. In this case, both $\mathrm{CO}$ and $\mathrm{C}_{2} \mathrm{H}_{4}$ are evolved throughout 


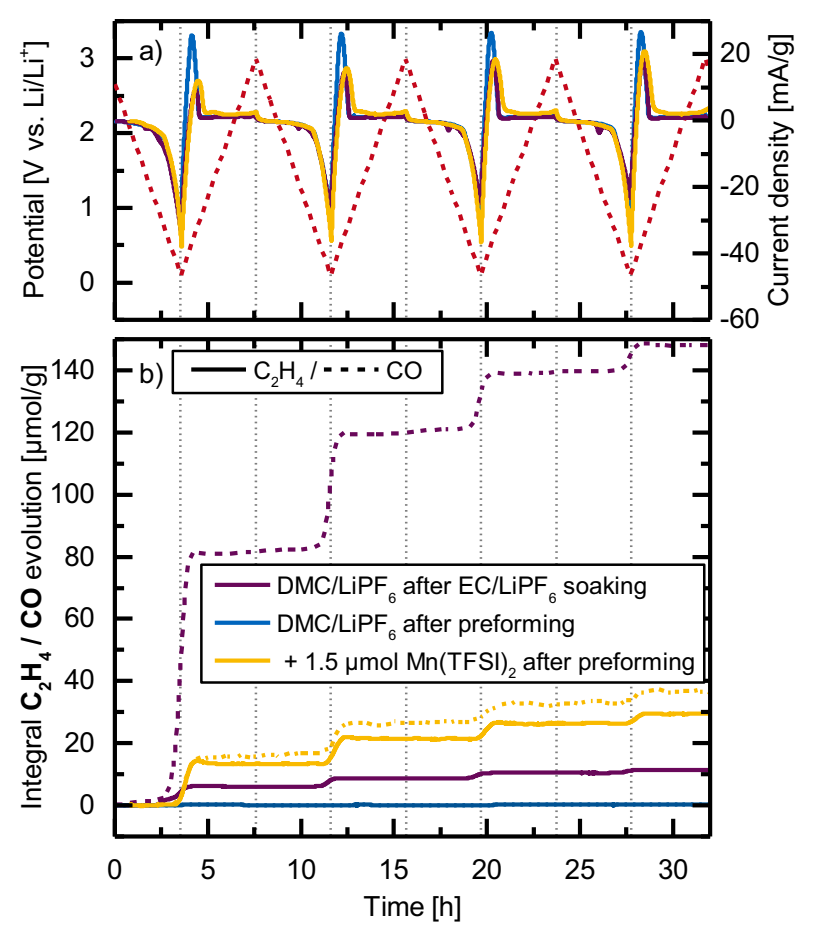

Figure 7. a) Currents normalized to graphite mass and b) evolution of ethylene (solid lines) and $\mathrm{CO}$ (dashed lines) during the first 4 voltammetric cycles of preformed graphite electrodes in $\mathrm{DMC}^{1} .5 \mathrm{M} \mathrm{LiPF}_{6}$ electrolyte without (blue

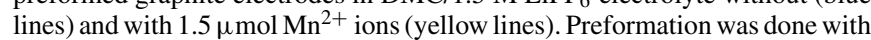
TM-free EC/1.5 M LiPF 6 electrolyte in a separate cell vs. an LFP cathode (2 cycles at $\mathrm{C} / 8$ ); harvested electrodes were washed with DMC prior to building the 2-compartment OEMS cells. To determine the efficacy of the washing procedure, a pristine graphite electrode soaked in $\mathrm{EC} / 1.5 \mathrm{M} \mathrm{LiPF}_{6}$ electrolyte and then washed was also examined (dark purple lines). The voltammetric cycles at $0.2 \mathrm{mV} / \mathrm{s}$ were done between $0.1-3.0 \mathrm{~V}$ vs. $\mathrm{Li}^{+} / \mathrm{Li}$, starting from OCV $\left(\sim 2.9 \mathrm{~V}\right.$ vs. $\left.\mathrm{Li}^{+} / \mathrm{Li}\right)$.

all 4 cycles. As the $\mathrm{C}_{2} \mathrm{H}_{4}$ evolution from the $\mathrm{Mn}^{2+}$-containing electrolyte is $\sim 30 \mu \mathrm{mol} / \mathrm{g}$ after 4 cycles (see solid yellow line in Figure 7b) while the EC residuals from the EC-soaked electrode account to only $\sim 11 \mu \mathrm{mol} / \mathrm{g} \mathrm{C}_{2} \mathrm{H}_{4}$ (see solid navy line in Figure $7 \mathrm{~b}$ ), we hypothesize that this additional $\sim 19 \mu \mathrm{mol} / \mathrm{g} \mathrm{C}_{2} \mathrm{H}_{4}$ originate from the decomposition of LEDC. This LEDC-derived amount of $\mathrm{C}_{2} \mathrm{H}_{4}$ may be compared to the higher amount of $\sim 69 \mu \mathrm{mol} / \mathrm{g} \mathrm{C}_{2} \mathrm{H}_{4}$ evolved for an identically preformed graphite electrode but cycled in $\mathrm{EC} / \mathrm{LiPF}_{6}+$ $\mathrm{Mn}^{2+}$ (Figure 3b, yellow lines). From this it becomes clear that the $\mathrm{Mn}$ catalyzed LEDC decomposition must compromise the integrity of the SEI, so that further electrolyte reduction can occur, namely of EC to $\mathrm{C}_{2} \mathrm{H}_{4}$ in the $\mathrm{EC} / \mathrm{LiPF}_{6}$ electrolyte. This hypothesis is confirmed by the strong $\mathrm{CO}$ evolution upon cycling of preformed graphite electrodes in the $\mathrm{Mn}^{2+}$-containing $\mathrm{DMC}^{2} \mathrm{LiPF}_{6}$ electrolyte (dashed yellow line in Figure $7 \mathrm{~b}$ ), where a major fraction of the evolved gas is produced by the direct reduction of DMC to CO. In summary, the comparison of the gas evolution of graphite electrodes preformed in $\mathrm{EC}^{\mathrm{L}} \mathrm{LiPF}_{6}$ and then cycled in $\mathrm{Mn}^{2+}$-containing EC/LiPF 6 (Figure 3b) vs. $\mathrm{Mn}^{2+}$ containing $\mathrm{DMC}^{-\mathrm{LiPF}_{6}}$ (Figure $7 \mathrm{~b}$ ) reveals that the $\mathrm{Mn}$ catalyzed LEDC decomposition of LEDC must be leading to morphological changes in the SEI which leads to further electrolyte decomposition.

Based on our here presented results and numerous previous studies, we suggest the following mechanism for the catalytic decomposition of electrolyte by manganese ions, which is sketched in Scheme 1: After the $\mathrm{Mn}^{2+}$ ions are absorbed into the SEI by ion exchange (process (1) in Scheme 1), they diffuse through the SEI until they are close enough for an electron transfer from the lithiated graphite via tunneling, which leads to the deintercalation of lithium from graphite (2). If the reduced manganese is surrounded by LEDC, the latter is reduced to $\mathrm{Li}_{2} \mathrm{CO}_{3}$ and $\mathrm{C}_{2} \mathrm{H}_{4}$, while the manganese is simultaneously oxidized back to

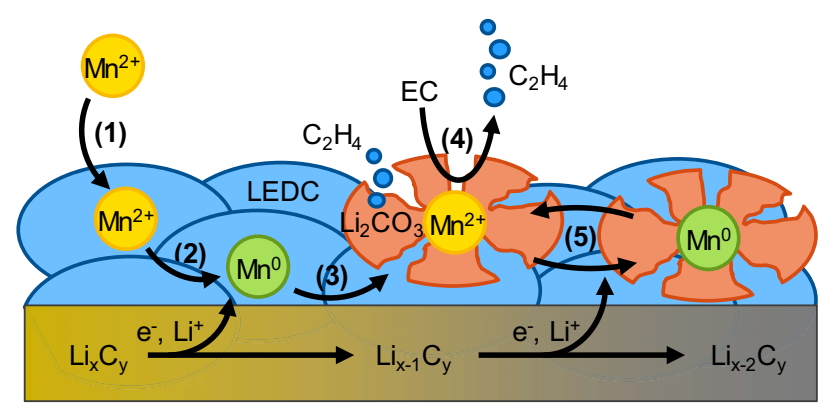

Scheme 1. Proposed mechanism for the continuous decomposition of SEI and electrolyte as monitored by $\mathrm{C}_{2} \mathrm{H}_{4}$ evolution for a preformed electrode with a $\mathrm{Mn}^{2+}$-containing electrolyte (see text for details): (1) Absorption of $\mathrm{Mn}^{2+}$ ions into the SEI; (2) reduction of $\mathrm{Mn}^{2+}$ ions in the SEI and deintercalation of $\mathrm{Li}^{+}$from graphite; (3) re-oxidation of $\mathrm{Mn}^{0}$ to $\mathrm{Mn}^{2+}$; (4) recurrent electrolyte reduction; (5) catalytic cycle of electrolyte decomposition.

$\mathrm{Mn}^{2+}$ (3). Alternatively, LEDC could be reduced to lithium alkoxides and $\mathrm{CO}_{2}^{-}$as suggested by Leung, ${ }^{50}$ eventually also forming $\mathrm{Li}_{2} \mathrm{CO}_{3}$. The reduction contracts the SEI in the vicinity, leading to cracks which are filled with fresh electrolyte. This electrolyte will be reduced (4), and, if EC-based, produce additional $\mathrm{C}_{2} \mathrm{H}_{4}$. Consequently, $\mathrm{Mn}^{2+}$ would be located at the border between organic and inorganic SEI, in agreement with previous observations..$^{25,32,37,38} \mathrm{The} \mathrm{Mn}^{2+}$ ion can now accept further electrons and pass them on to surrounding LEDC or EC molecules (5), thereby leading to a catalytic cycle of electrolyte decomposition and active lithium loss from the lithiated graphite. This cycle can continue until the $\mathrm{Mn}^{2+}$ ion is eventually fully encapsulated by non-reducible decomposition products, so that an electron transfer from the lithiated graphite is no longer feasible. As Wandt et al. ${ }^{4}$ found manganese almost exclusively in its $2+$ oxidation state by operando XAS, the re-oxidation of $\mathrm{Mn}^{0}$ to $\mathrm{Mn}^{2+}$ must be faster than the reduction of $\mathrm{Mn}^{2+}$, i.e., the diffusion within the SEI and the electron transfer (steps 2 and 5 in Scheme 1) are the rate-limiting steps.

While both nickel and manganese have shown activity toward electrolyte decomposition in their reduced state (i.e., on pristine electrodes, see Figure 1), the presence of a preformed SEI greatly suppressed the effect of $\mathrm{Ni}^{2+}$ containing electrolyte on both gas evolution (see Figure 3b, green line) and the enrichment of $\mathrm{Li}_{2} \mathrm{CO}_{3}$ in the SEI (see Figure 6, green line). Hence, we can assume that the diffusion and/or the electron transfer of $\mathrm{Ni}^{2+}$ within the SEI is slowed down compared to $\mathrm{Mn}^{2+}$. As suggested by Shkrob et al., ${ }^{38}$ it is possible that nickel and manganese are not fully reduced, but only one electron is transferred through the SEI to the transition metal ion. DFTcalculations by Leung ${ }^{50}$ indicate that a $\mathrm{Ni}(\mathrm{I})$ species is far less likely to transfer an electron to neighboring SEI molecules compared to its $\mathrm{Mn}(\mathrm{I})$ counterpart. In this case, the catalytic cycle for Ni would be effectively interrupted. Additionally, Wandt at al. ${ }^{4}$ found that $\mathrm{Mn}^{2+}$ in the SEI is reduced within minutes once the electrolyte is completely removed, whereas nickel stays in its $2+$ state. As the reduction potential of $\mathrm{Ni}^{2+} / \mathrm{Ni}$ is $\sim 1 \mathrm{~V}$ higher than the reduction potential of $\mathrm{Mn}^{2+} / \mathrm{Mn},{ }^{5,74}$ the electron transfer from lithiated graphite to $\mathrm{Ni}^{2+}$ should have a higher thermodynamic driving force. Hence, another possible reason for the apparent difference between $\mathrm{Ni}$ and $\mathrm{Mn}$ is that the $\mathrm{Li}^{+} / \mathrm{Ni}^{2+}$ exchange and the diffusion of $\mathrm{Ni}^{2+}$ within the $\mathrm{SEI}$ is much slower compared to $\mathrm{Mn}^{2+}$.

For Li-ion batteries, this has two implications: i) The same amount of TM dissolution leads to less severe capacity fading if the cathode active material is Ni-rich and $\mathrm{Mn}$-poor, which is advantageous for Ni-rich NMCs and especially Mn-free NCA (as seen by Gilbert et $\mathrm{al}^{7}$ ); ii) future additive design should focus on the formation of an SEI which enables $\mathrm{Li}^{+}$ion transport while slowing down the diffusion of all transition metal ions, or which form SEI products which consist of chemically stable species that cannot be further reduced. In this context, a thermally aged SEI that contains more LiF and other 
stable inorganic species ${ }^{75}$ might be more robust toward the detrimental side reactions induced by manganese ions. However, as $\mathrm{Mn}^{2+}$ rapidly exchanges with $\mathrm{Li}^{+}$from $\mathrm{LiF}$ in the $\mathrm{SEI},{ }^{25,37}$ a high $\mathrm{LiF}$ content will likely not act as a barrier for $\mathrm{Mn}^{2+}$ diffusion.

\section{Conclusions}

In this work, we applied on-line electrochemical mass spectrometry (OEMS) to follow the reactions triggered by manganese and nickel that ultimately lead to the loss of active lithium and poor capacity retention in full-cells. For the first time, we have investigated the effect of $\mathrm{Mn}^{2+}$ and $\mathrm{Ni}^{2+}$ on the gassing behavior of graphite, using EC/LiPF 6 model electrolytes with $\mathrm{Mn}(\mathrm{TFSI})_{2}$ or $\mathrm{Ni}(\mathrm{TFSI})_{2}$ in a 2-compartment cell. Both manganese and nickel significantly increase the $\mathrm{C}_{2} \mathrm{H}_{4}$ evolution and thus ethylene carbonate (EC) reduction on pristine graphite electrodes. Furthermore, the $\mathrm{Mn}^{2+}$-containing electrolyte showed an ongoing EC reduction and $\mathrm{C}_{2} \mathrm{H}_{4}$ evolution throughout several cycles after formation.

As a second step, we investigated the effect of $\mathrm{Mn}^{2+}$ and $\mathrm{Ni}^{2+}$ on graphite electrodes which already featured an SEI by preforming them in a TM-free electrolyte. We found that the effect of nickel is greatly suppressed by the SEI, whereas manganese showed almost the same activity toward electrolyte reduction as on pristine electrodes. However, a preformation in a VC-containing electrolyte could significantly lower the side reactions caused by $\mathrm{Mn}^{2+}$ ions. As this showed that the SEI chemistry plays a crucial role, we found by post-mortem ATR-FTIR spectroscopy that the graphite electrodes cycled in an $\mathrm{Mn}^{2+}$-containing electrolyte consisted of more $\mathrm{Li}_{2} \mathrm{CO}_{3}$ compared to electrodes cycled in an electrolyte with $\mathrm{Ni}^{2+}$ ions or no transition metals. Further OEMS experiments with preformed graphite electrodes and a DMC electrolyte (which allowed us to distinguish between electrolyte reduction and SEI decomposition) indicated that $\mathrm{Mn}^{2+}$ leads to the decomposition of LEDC to $\mathrm{C}_{2} \mathrm{H}_{4}$ and $\mathrm{Li}_{2} \mathrm{CO}_{3}$; however, the major part of the gas evolution still originated directly from the electrolyte reduction. Our results suggest that cathode active materials with low or zero manganese contents should be advantageous with respect to the detrimental effects of transition metal dissolution, and that SEI-stabilizing additives can be an efficient way to decrease the side reactions caused by transition metal ions in Li-ion batteries.

\section{Acknowledgments}

Sophie Solchenbach gratefully acknowledges the BASF Battery Research Network for financial support. Funding for Roland Jung was provided by BMW AG. The authors thank Prof. Brett Lucht for fruitful discussions.

\section{ORCID}

Sophie Solchenbach (D) https://orcid.org/0000-0001-6517-8094

Roland Jung $\mathbb{D}$ https://orcid.org/0000-0003-1135-7438

\section{References}

1. Y. Terada, Y. Nishiwaki, I. Nakai, and F. Nishikawa, J. Power Sources, 97-98, 420 (2001).

2. H. Tsunekawa, S. Tanimoto, R. Marubayashi, M. Fujita, K. Kifune, and M. Sano, J. Electrochem. Soc., 149, A1326 (2002).

3. D. H. Jang, Y. J. Shin, and S. M. Oh, J. Electrochem. Soc., 143, 2204 (1996).

4. J. Wandt, A. Freiberg, R. Thomas, Y. Gorlin, A. Siebel, R. Jung, H. A. Gasteiger, and M. Tromp, J. Mater. Chem. A, 4, 18300 (2016).

5. R. Jung, F. Linsenmann, R. Thomas, J. Wandt, S. Solchenbach, F. Maglia, C. Stinner, M. Tromp, and H. A. Gasteiger, manuscript in preparation (2018).

6. H. Zheng, Q. Sun, G. Liu, X. Song, and V. S. Battaglia, J. Power Sources, 207, 134 (2012).

7. J. A. Gilbert, I. A. Shkrob, and D. P. Abraham, J. Electrochem. Soc., 164, 389 (2017)

8. D. R. Gallus, R. Schmitz, R. Wagner, B. Hoffmann, S. Nowak, I. Cekic-Laskovic, R. W. Schmitz, and M. Winter, Electrochim. Acta, 134, 393 (2014).

9. I. Buchberger, S. Seidlmayer, A. Pokharel, M. Piana, J. Hattendorff, P. Kudejova, R. Gilles, and H. A. Gasteiger, J. Electrochem. Soc., 162, A2737 (2015).

10. D. P. Abraham, T. Spila, M. M. Furczon, and E. Sammann, Electrochem. Solid-State Lett., 11, A226 (2008)
11. X. Liao, Q. Huang, S. Mai, X. Wang, M. Xu, L. Xing, Y. Liao, and W. Li, J. Power Sources, 286, 551 (2015)

12. M. Metzger, B. Strehle, S. Solchenbach, and H. A. Gasteiger, J. Electrochem. Soc., 163, A798 (2016)

13. S. Solchenbach, M. Metzger, M. Egawa, H. Beyer, and H. A. Gasteiger, J. Electrochem. Soc., 165, A3022 (2018)

14. T. Li, L. Xing, W. Li, Y. Wang, M. Xu, F. Gu, and S. Hu, J. Power Sources, 244, 668 (2013).

15. O. Borodin, W. Behl, and T. R. Jow, J. Phys. Chem. C, 117, 8661 (2013).

16. D. H. Jang and S. M. Oh, J. Electrochem. Soc., 144, 3342 (1997)

17. K. Amine, J. Liu, S. Kang, I. Belharouak, Y. Hyung, D. R. Vissers, and G. L. Henriksen, J. Power Sources, 129, 14 (2004).

18. R. Jung, M. Metzger, F. Maglia, C. Stinner, and H. A. Gasteiger, J. Electrochem. Soc., 164, A1361 (2017)

19. R. Jung, M. Metzger, F. Maglia, C. Stinner, and H. A. Gasteiger, J. Phys. Chem. Lett., 8, 4820 (2017).

20. J. Wandt, A. Freiberg, A. Ogrodnik, and H. A. Gasteiger, Mater. Today, in press (2018).

21. D. Streich, C. Erk, A. Gue, P. Mu, F.-F. Chesneau, and E. J. Berg, J. Phys. Chem. C 121, 13481 (2017)

22. D. Streich, A. Guéguen, M. A. Mendez, F. F. Chesneau, P. Novák, and E. J. Berg, J. Electrochem. Soc., 163, A964 (2016).

23. A. Freiberg, S. Solchenbach, B. Strehle, A. Siebel, M. Tromp, and H. A. Gasteiger, ECS Meet. Abstr., 2, 179 (2018).

24. C. Zhan, J. Lu, A. J. Kropf, T. Wu, A. N. Jansen, Y. K. Sun, X. Qiu, and K. Amine, Nat. Commun., 4, 2437 (2013).

25. D. R. Vissers, Z. Chen, Y. Shao, M. H. Engelhard, U. Das, P. C. Redfern, L. A. Curtiss, B. Pan, J. Liu, and K. Amine, ACS Appl. Mater. Interfaces, 8, 14244 (2016).

26. W. Choi and A. Manthiram, J. Electrochem. Soc., 153, A1760 (2006).

27. C. Zhan, T. Wu, J. Lu, and K. Amine, Energy Environ. Sci., 11, 243 (2018).

28. T. Tsujikawa, K. Yabuta, and T. Matsushita, J. Electrochem. Soc., 158, 322 (2011).

29. N. P. W. Pieczonka, Z. Liu, P. Lu, K. L. Olson, J. Moote, B. R. Powell, and J. Kim, J. Phys. Chem. C, 117, 15947 (2013).

30. L. M. Thompson, W. Stone, A. Eldesoky, N. K. Smith, C. R. M. Mcfarlane, J. S. Kim, M. B. Johnson, R. Petibon, and J. R. Dahn, 165, 2732 (2018).

31. S. Komaba, N. Kumagai, and Y. Kataoka, Electrochim. Acta, 47, 1229 (2002).

32. T. Joshi, K. Eom, G. Yushin, and T. F. Fuller, J. Electrochem. Soc., 161, A1915 (2014).

33. M. Ochida, Y. Domi, T. Doi, S. Tsubouchi, H. Nakagawa, T. Yamanaka A. Abouimrane, and Z. Ogumi, J. Electrochem. Soc., 159, A961 (2012)

34. D. Pritzl, J. Landesfeind, S. Solchenbach, and H. A. Gasteiger, J. Electrochem. Soc., 165, A2145 (2018).

35. C. Zhan, X. Qiu, J. Lu, and K. Amine, Adv. Mater. Interfaces, 3, 1500856 (2016).

36. Y. K. Lee, J. Park, and W. Lu, J. Electrochem. Soc., 164, 2812 (2017)

37. H. Shin, J. Park, A. M. Sastry, and W. Lu, J. Power Sources, 284, 416 (2015).

38. I. A. Shkrob, A. J. Kropf, T. W. Marin, Y. Li, O. G. Poluektov, J. Niklas, and D. P. Abraham, J. Phys. Chem. C, 118, 24335 (2014).

39. C. Delacourt, A. Kwong, X. Liu, R. Qiao, W. L. Yang, P. Lu, S. J. Harris, and V. Srinivasan, J. Electrochem. Soc., 160, A1099 (2013).

40. T. Nordh, S. R. Younesi, M. Hahlin, R. F. Duarte, C. Tengstedt, D. Brandell, and K. Edström, J. Phys. Chem. C, 120, 3206 (2016).

41. S. Komaba, T. Itabashi, T. Ohtsuka, H. Groult, N. Kumagai, B. Kaplan, and H. Yashiro, J. Electrochem. Soc., 152, A937 (2005).

42. X. Xiao, Z. Liu, L. Baggetto, G. M. Veith, K. L. More, and R. R. Unocic, Phys. Chem. Chem. Phys., 16, 10398 (2014).

43. S. R. Gowda, K. G. Gallagher, J. R. Croy, M. Bettge, M. M. Thackeray, and M. Balasubramanian, Phys. Chem. Chem. Phys., 16, 6898 (2014).

44. M. J. Aragon, C. Pérez-Vicente, and J. L. Tirado, Electrochem. commun., 9, 1744 (2007).

45. S. Mirhashemihaghighi, B. Leo, C. Pe, J. L. Tirado, and E. M. Arroyo, Inorg. Chem., 51, 5554 (2012).

46. Y. T. Teng, S. S. Pramana, J. Ding, T. Wu, and R. Yazami, Electrochim. Acta, 107, $301(2013)$

47. D. H. Lee, K. J. Carroll, K. W. Chapman, O. J. Borkiewicz, S. Calvin, E. E. Fullerton, and Y. S. Meng, Phys. Chem. Chem. Phys., 16, 3095 (2014).

48. K. Rui, Z. Wen, Y. Lu, J. Jin, and C. Shen, Adv. Energy Mater, 5, 1401716 (2015)

49. Y.-K. Han, K. Lee, S. Kang, Y. Suk, and H. Lee, Comput. Mater. Sci., 81, 548 (2014)

50. K. Leung, Chem. Mater, 29, 2550 (2016).

51. R. Imhof and P. Novák, J. Electrochem. Soc., 145, 1081 (1998)

52. B. Zhang, M. Metzger, S. Solchenbach, M. Payne, S. Meini, H. A. Gasteiger, A. Garsuch, and B. L. Lucht, J. Phys. Chem. C, 119, 11337 (2015).

53. N. Tsiouvaras, S. Meini, I. Buchberger, and H. A. Gasteiger, J. Electrochem. Soc., 160, A471 (2013)

54. M. Metzger, C. Marino, J. Sicklinger, D. Haering, and H. A. Gasteiger, J. Electrochem. Soc., 162, A1123 (2015).

55. B. Strehle, S. Solchenbach, M. Metzger, K. U. Schwenke, and H. A. Gasteiger, J. Electrochem. Soc., 164, A2513 (2017).

56. Y. Peng and P. Wu, Polymer (Guildf)., 45, 5295 (2004).

57. D. Strmcnik, I. E. Castelli, J. G. Connell, D. Haering, M. Zorko, P. Martins, P. P. Lopes, B. Genorio, T. Østergaard, H. A. Gasteiger et al., Nat. Catal., 1, 255 (2018).

58. U. Heider, R. Oesten, and M. Jungnitz, J. Power Sources, 7 (1999).

59. D. Aurbach, Y. Gofer, M. Ben-Zion, and P. Aped, J. Electroanal. Chem., 339, 451 (1992).

60. M. Nie, D. Chalasani, D. P. Abraham, Y. Chen, A. Bose, and B. L. Lucht, J. Phys. Chem. C, 117, 1257 (2013). 
61. D. Aurbach, Y. Ein-Ely, and A. Zaban, J. Electrochem. Soc., 141, L1 (1994).

62. H. Ota, Y. Sakata, A. Inoue, and S. Yamaguchi, J. Electrochem. Soc., 151, A1659 (2004).

63. R. Bernhard, S. Meini, and H. A. Gasteiger, J. Electrochem. Soc., 161, A497 (2014).

64. R. Bernhard, M. Metzger, and H. A. Gasteiger, J. Electrochem. Soc., 162, A1984 (2015).

65. M. Onuki, S. Kinoshita, Y. Sakata, M. Yanagidate, Y. Otake, M. Ue, and M. Deguchi, J. Electrochem. Soc., 155, A794 (2008).

66. H. Yoshida, T. Fukunaga, T. Hazama, M. Terasaki, M. Mizutani, and M. Yamachi, $J$. Power Sources, 68, 311 (1997).

67. K. Leung, Chem. Phys. Lett., 568-569, 1 (2013).

68. R. Mogi, M. Inaba, Y. Iriyama, T. Abe, and Z. Ogumi, J. Power Sources, 119-121, 597 (2003)
69. A. L. Michan, B. S. Parimalam, M. Leskes, R. N. Kerber, T. Yoon, C. P. Grey, and B. L. Lucht, Chem. Mater, 28, 8149 (2016).

70. D. Pritzl, S. Solchenbach, M. Wetjen, and H. A. Gasteiger, J. Electrochem. Soc., 164, A2625 (2017).

71. L. Gireaud, S. Grugeon, S. Laruelle, S. Pilard, and J.-M. Tarascon, J. Electrochem. Soc., 152, A850 (2005).

72. D. M. Seo, D. Chalasani, B. S. Parimalam, R. Kadam, M. Nie, and B. L. Lucht, ECS Electrochem. Lett., 3, A91 (2014).

73. Y. Ein-Eli, B. Markovsky, D. Aurbach, Y. Carmeli, H. Yamin, and S. Luski, Electrochim. Acta, 39, 2559 (1994).

74. P. Vanýsek, in CRC Handbook of Chemistry and Physics, W. Haynes, Editor, CRC Press LLC (2000).

75. B. S. Parimalam, A. D. Macintosh, R. Kadam, and B. L. Lucht, J. Phys. Chem. C, 121, 22733 (2017) 